\title{
International Financial Spillovers to Emerging Market Economies: How Important Are Economic Fundamentals?
}

Ahmed Shaghil, Brahima Coulibaly, and Andrei Zlate

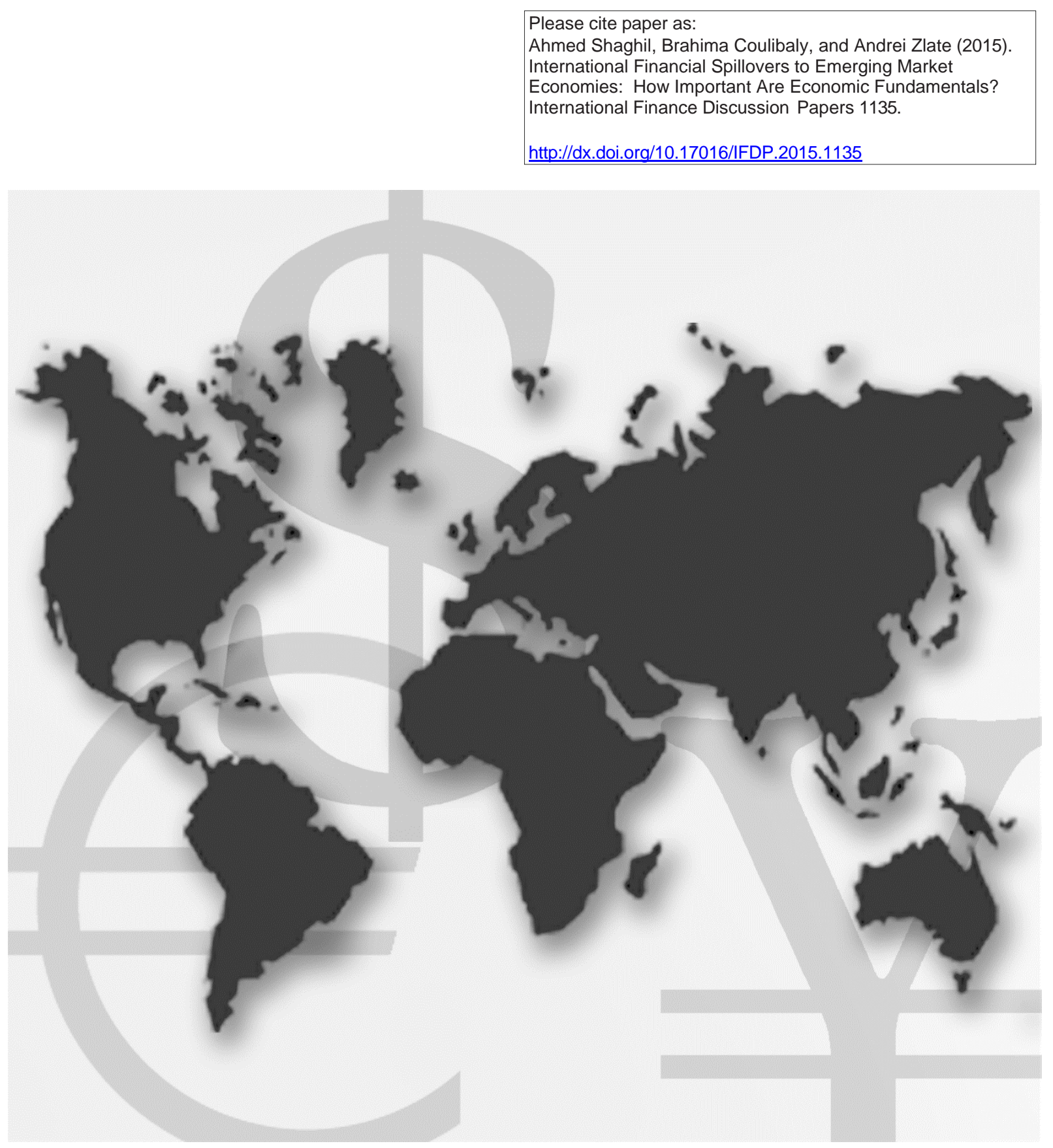

\section{International Finance Discussion Papers}

Board of Governors of the Federal Reserve System 
Board of Governors of the Federal Reserve System

International Finance Discussion Papers

Number 1135

April 2015

\title{
International Financial Spillovers to Emerging Market Economies: How Important Are Economic Fundamentals?
}

\author{
Shaghil Ahmed, Brahima Coulibaly, Andrei Zlate*
}

NOTE: International Finance Discussion Papers are preliminary materials circulated to stimulate discussion and critical comment. References to International Finance Discussion Papers (other than an acknowledgment that the writer has had access to unpublished material) should be cleared with the author or authors. Recent IFDPs are available on the Web at www.federalreserve.gov/pubs/ifdp/. This paper can be downloaded without charge from the Social Science Research Network electronic library at www.ssrn.com. 


\title{
International Financial Spillovers to Emerging Market Economies: How Important Are Economic Fundamentals?
}

\author{
Shaghil Ahmed, Brahima Coulibaly, Andrei Zlate*
}

April 2015

\begin{abstract}
We assess the importance of economic fundamentals in the transmission of international shocks to financial markets in various emerging market economies (EMEs). Our analysis covers the socalled taper-tantrum episode of 2013 and six earlier episodes of severe EME-wide financial stress since the mid-1990s. Cross-country regressions lead us to the following results: (1) EMEs with relatively better economic fundamentals suffered less deterioration in financial markets during the 2013 taper-tantrum episode. (2) Differentiation among EMEs set in quite early and persisted throughout this episode. (3) Controlling for economic fundamentals, we also find that, during the taper tantrum, financial conditions deteriorated more in those EMEs that had earlier experienced larger private capital inflows and greater exchange rate appreciation. (4) For earlier episodes, we find little evidence of investor differentiation across EMEs being explained by differences in their relative vulnerabilities during EME crises of the 1990s and early 2000s. (5) That said, differentiation across EMEs based on fundamentals does not appear to be unique to the 2013 episode. Differences in economic fundamentals played a role in explaining the heterogeneous EME financial market responses during the global financial crisis of 2008, and the role of fundamentals appeared to progressively increase through the European crisis in 2011 and subsequently the 2013 taper tantrum.
\end{abstract}

Keywords: Emerging market economies, financial spillovers, economic fundamentals, vulnerability, depreciation pressure, taper tantrum, financial stress.

JEL classifications: E5, F3.

*Shaghil Ahmed (shaghil.ahmed@frb.gov) and Brahima Coulibaly (brahima.coulibaly@frb.gov) are economists in the Division of International Finance, Board of Governors of the Federal Reserve System, Washington, D.C. 20551 U.S.A. Andrei Zlate (andrei.zlate@bos.frb.org) is a financial economist in the Department of Supervision, Regulation, and Credit at the Federal Reserve Bank of Boston, 600 Atlantic Avenue, Boston, MA 02210, U.S.A. We thank Steve Kamin, Prachi Mishra, Patrice Robitaille, as well as participants at the American Economic Association 2015 annual meetings and the Federal Reserve Board conference on "Spillovers from Accommodative Monetary Policies since the GFC” for very useful comments. We also thank Zina Saijid and Julio Ortiz for outstanding research assistantship. The views expressed in the paper are those of the authors and should not be interpreted as reflecting the views of the Board of Governors of the Federal Reserve System or any other person associated with the Federal Reserve System. 


\section{Introduction}

Starting in May 2013, on news that the Federal Reserve could soon start tapering its large scale asset purchases (LSAPs), financial conditions in emerging market economies (EMEs) deteriorated sharply. Investors withdrew capital, currencies depreciated, stock markets fell, and bond yields and premiums on credit default swaps rose. This so-called taper-tantrum episode sparked debate on how foreign economies may be affected - and which economies, especially among the EMEs, may experience the most adverse effects - once the process of U.S. monetary policy normalization begins.

Indeed, one intriguing feature of the "risk-off" episode during the summer and fall of 2013 was that it did not have a similar effect on all EMEs. While some countries experienced acute deteriorations in financial conditions, others were much less affected. The varied experiences of the different EMEs have spawned research on whether the heterogeneous response of EME financial markets during the taper tantrum can be explained by differences in economic fundamentals across these economies. (See, for example: Prachi et al., 2014; Eichengreen and Gupta, 2014; Aizenman et al., 2014; and Sahay et al., 2014.) And, these experiences have also focused attention on whether, more broadly, the effects of U.S. monetary policy shocks on EMEs over a longer period have been related to these economies' own vulnerabilities (Bowman et al., 2014).

In this paper, we seek to contribute to this sparse but growing literature. Specifically, we address three questions: First, to what extent did investors differentiate among the EMEs based on their economic fundamentals during the "risk-off" episode of 2013? Or, can the heterogeneous responses across EMEs be explained by other factors, such as whether those economies that initially received the heaviest capital inflows were also the ones from which investors receded the most during the episode, a possibility raised by some researchers such as Aizenman et al. (2014). Second, during the taper-tantrum stress episode, when exactly did differentiation across EMEs begin and how persistent was it? Did investors initially display herd behavior and pull back indiscriminately from all EMEs, and then only begin differentiating over time as the shock persisted? Or did they discriminate across EMEs from the early stages of the episode? Third, is the differentiation across EMEs by investors a relatively recent phenomenon, or does the application of our methodology suggest that investors have always distinguished among EMEs to some extent according to their economic fundamentals? 
Research to date has not appeared to reach a consensus on the first question - the importance of fundamentals in explaining the heterogeneous EME responses. Using an event study approach, Prachi et al. (2014) analyze the reaction of financial markets to the Federal Reserve's LSAPs tapering announcements in 2013 and 2014, including the episode that we examine in this study. They find evidence of market differentiation among EMEs based on macroeconomic fundamentals. In addition, they find that EMEs with deeper financial markets and tighter macroprudential policy prior to the stress period experienced relatively less deterioration in financial conditions.

In contrast, Eichengreen and Gupta (2014) do not find evidence that better macroeconomic fundamentals - such as a lower budget deficit, lower public debt, a higher level of international reserves, and higher economic growth-provided any insulation. They do find, however, that EMEs whose exchange rates appreciated more earlier and whose current account deficits widened more experienced a larger effect. But they conclude that the heterogeneous reactions most importantly owed to the size of each country's financial market; larger markets experienced more pressure, as investors were better able to rebalance their portfolios in these EMEs with relatively large and liquid financial markets. Similarly, Aizenman et al. (2014) find no evidence that stronger macroeconomic fundamentals helped the EMEs weather the taper tantrum better, but their study focuses only on the very short-term responses of financial indicators after taper news. Classifying EMEs into two categories ("fragile" and "robust") based on their current account balances, levels of international reserves, and external debt, they find that news of tapering from Fed Chairman Bernanke was associated with sharper deterioration of financial conditions in the "robust" EMEs compared with the "fragile" ones in the very short term (24 hours following the announcement). The authors rationalize their results by conjecturing that EMEs with stronger fundamentals received more capital inflows during the expansionary phase of the Federal Reserve's conventional and unconventional monetary policy and accordingly experienced sharper capital outflows and deteriorations in financial conditions on news of an impending tapering. This hypothesis is not explicitly tested in their study, and the authors acknowledge that, over a longer window than they considered in their event study, the fragile EMEs may have suffered more than robust EMEs after the taper news.

We approach the first question in a somewhat different manner from these previous studies. Rather than looking at market reactions on days when news may be coming in about the Federal Reserve's tapering of asset purchases as Prachi et al. (2014) do, we treat the taper tantrum as a single episode, defined by the observed "peak-to-trough" behavior of financial markets surrounding 
the period when concerns about tapering came to the forefront. And unlike Aizenman et al. (2014), but consistent with Prachi et al. (2014), we exploit finer cross-section differences in vulnerabilities across the EMEs rather than divide the EMEs into two groups based on the behavior of only three variables. Using a sample of 20 emerging market economies and cross-section regression analysis, we assess the role of economic fundamentals in the heterogeneous cumulative performance of EME financial markets over the whole episode from May 2013 through August 2013.

We find that EMEs that had relatively better fundamentals to begin with - as measured by a host of individual variables capturing vulnerability as well as an aggregate index of relative vulnerabilities across EMEs that we construct - suffered less deterioration during the taper-tantrum episode as measured by a broad range of financial variables, including exchange rate, depreciation pressure, and government bond yields, as well as EMBI and CDS spreads. Our results are consistent with those in Prachi et al. (2014), but contrast with those in Aizenman et al. (2014) and Eichengreen and Gupta (2014). We also find that financial conditions deteriorated more in those EMEs that had earlier experienced larger private capital inflows and exchange rate appreciations, consistent with the "more-in-more-out" hypothesis that EMEs that experienced larger inflows prior to the taper tantrum also experienced larger outflows once the episode began. Also, we find some evidence that the structure of the financial markets - such as the size of the capital market, the level of foreign investor participation, the extent of capital account openness, or revisions to the growth outlook - shaped the heterogeneous responses of some financial indicators, as in Eichengreen and Gupta (2014). However, the strength of economic fundamentals explains much more of the variation in responses across EMEs compared with other factors, such as the previous runup in flows or the structure of financial markets.

On the second question, related to the timing and persistence of differentiation, the conventional wisdom seems to be that early in the taper tantrum, investors did not differentiate much among EMEs according to their vulnerabilities, but such differences emerged when concerns about tapering persisted. (See, for example, Sahay et al., 2014). However, our evidence suggests that differentiation according to relative vulnerabilities set in relatively early during the stress episode and persisted for some time, although the extent of differentiation was less pronounced in the first few weeks.

Turning to the third question of the extent to which investors also discriminated among EMEs in the past, we use our methodology to identify six previous episodes of severe financial stress in the EMEs over the past 20 years: the European sovereign debt crisis (2011), the global financial crisis 
(GFC, 2008-09), the Argentine crisis (2002), the Russian crisis (1998), the Asian crisis (1997-98), and the Mexican crisis (1994-95). For each of these episodes, we examine the role of economic fundamentals in driving any heterogeneous cumulative reaction of asset prices over the full episode across EMEs. We find little evidence of differentiation based on economic fundamentals in the 1990s and the early 2000s, consistent with literature on herding behavior of investors toward EMEs and contagion during that period, such as Dornbusch et al. (2000) and Calvo and Mendoza (2001). However, the results also suggest that differentiation was not unique to the taper tantrum in 2013. In fact, it appears that fundamentals played a role in explaining the heterogeneous reaction of EME asset prices during the GFC in 2008, and that their role increased during the European sovereign crisis in 2011, and then increased further during the taper tantrum in mid-2013. These results that differentiation has occurred among EMEs since the GFC are consistent with those from a complementary approach taken in Bowman et al. (2014): identifying monetary policyrelated shocks to U.S. interest rates, rather than episodes of severe financial stress as we do, they find that the effect of such shocks on EME interest rates have been larger in the relatively more vulnerable EMEs in the recent past as well, and that there is no difference in this respect between the effects of conventional and unconventional U.S. monetary policy.

Taken at face value, our results suggest that international investors may have moved from herd behavior in the past - such as during the 1990s and the early 2000s - to progressively differentiating more and more among EMEs according to their economic fundamentals through the GFC, the European debt crisis, and the taper tantrum. It remains an open question, however, whether our results are perhaps driven by different sources of the shock. The stress episodes since the GFC, during which we find evidence of differentiation among EMEs, emanated primarily from the advanced economies, whereas the crises of the 1990s and 2000s, during which we find little evidence of differentiation, emanated to a much larger extent-although not exclusively so-from shocks originating in the EMEs themselves.

The remainder of the study is organized as follows: In section 2, we describe the data and the estimation strategy. Then, section 3 presents our results of differentiation across EMEs during the 2013 taper-tantrum episode, and section 4 shows the results for differentiation in previous well-recognized EME financial stress episodes. section 5 concludes. 


\section{Econometric specification and choice of variables}

For each EME stress episode identified, we regress performance in selected financial markets across EMEs over the duration of the stress period on a set of variables capturing economic conditions that existed prior to the beginning of the stress episode and other control variables. Our cross-section regression is represented by the following equation:

$$
\Delta \operatorname{FinVar}_{i, k}=c+\sum_{j} \beta_{i, j} X_{i, j}+\varepsilon_{i}
$$

Note that each $i$ denotes a particular country, and each $k$ denotes a particular financial variable with its performance over the stress episode represented by $\Delta . X_{i, j}$ are a set of explanatory variables $j$ specific to country $i$ measured in the year prior to the onset of the stress period, $\beta$ 's are parameters to be estimated, and $\varepsilon$ 's are error terms. Data availability across countries and time limits our sample to 20 EMEs. ${ }^{1}$ Note that the cross-section observations in each regression are the countries, and a separate regression is run for each dependent variable $k$ and each sub-set of explanatory variables $j$.

Among the dependent variables measuring financial performance, we consider the percent change in the country's bilateral nominal exchange rate against the dollar, the change in the local currency bond yields on 10-year government bonds, the percent change in the stock market index, and the change in EMBI and CDS spreads between the peak and trough of each episode (for example, from April to August for the 2013 episode) using monthly data. ${ }^{2}$ Pressures on financial markets may not necessarily be reflected in the exchange rate if the central bank intervenes in foreign exchange markets to prop up the currency or raises the policy rate to contain capital flight. For this reason, we also consider a depreciation pressure index that is a weighted average of the change in the exchange rate and the foreign exchange reserves, following Eichengreen et al. (1995), with the weights given by the inverse of the standard deviation of each financial indicator measured in the cross section. ${ }^{3}$

\footnotetext{
1 Argentina, Brazil, China, Chile, Colombia, Indonesia, India, South Korea, Malaysia, Mexico, Peru, Paraguay, the Philippines, Pakistan, Russia, South Africa, Taiwan, Thailand, Turkey, and Uruguay. Although data for some countries were available, we exclude euro-area countries, dollarized economies, and the EMEs with hard peg exchange rate regimes.

2 The monthly data reflect end-of-month values for exchange rates, foreign exchange reserves, and policy interest rates, and average monthly values for bond yields, stock market indices, and EMBI and CDS spreads.

${ }^{3}$ Alternatively, we also constructed a depreciation pressure index based on the changes in exchange rates, foreign exchange reserves, and the policy rates between April and August 2013. Since the two indexes behave similarly during the taper-tantrum episode, our results are mostly based on the standard depreciation index based on changes
} 
We consider several different types of independent variables: those that might be capturing the macroeconomic fundamentals and policy choices of a country (category 1), those that might help identify how much capital might have been flowing in prior to the episode so we can test the "more-in-more out" hypothesis (category 2), and those that might be capturing aspects of a country's financial structure such as openness and financial development (category 3), which are included as other control variables.

Potential candidates for category 1 include the following six variables reflecting the strength of macroeconomic fundamentals: the current account balance as a percent of GDP; foreign exchange reserves as a percent of GDP; short-term external debt as a percent of foreign exchange reserves; the gross government debt as a percent of GDP; the average annual inflation over the past three years; and the runup in bank credit to the private sector, measured as the change in the ratio of bank credit to GDP over the five years prior. To mitigate concerns over endogeneity, each of these is taken as of the year prior to the one in which the episode occurs. For the 2013 event, we also use the revisions to the outlook for economic activity as an additional variable capturing fundamentals since analysts were, at least anecdotally, pointing to this as an important factor. The revisions to the outlook are measured as the change between January and May of 2013 in the outlook for annual average real GDP growth for 2013 provided by Consensus Economics. Finally, we account for the monetary policy and exchange rate frameworks through two indicator variables with the first variable equal to 1 for countries operating under an inflation targeting regime and 0 if not, and the second variable equal to 1 for countries with floating exchange rate regimes based on the classification in the IMF's Annual Report on Exchange Rate Arrangements and Exchange Restrictions, and 0 otherwise. Given the relatively small cross-section, not all of these variables can be included simultaneously; we consider individual variables one at a time and sub-sets of them. We also compute an aggregate index of relative vulnerabilities across the cross-section using some of these variables in light of the limited number of observations; this vulnerability index is described in detail in section 3.2.2.

For category 2, we include the following variables: the cumulative gross capital inflows over the past three years as a percent of GDP and the appreciation of the real effective exchange over the past three years. For category 3 variables, we consider the capitalization of the domestic equity market as a share of GDP; foreign participation in the domestic equity market, measured as the in exchange rates and reserves only. 
share of foreign equity holdings in the domestic equity market; and capital account openness, as measured by the Chinn-Ito index, a de jure measure of financial openness initially introduced in Chinn and Ito (2008) and subsequently updated by the authors through 2011. For each of these indicators, the data sources are presented in table 1.

\section{Differentiation across EMEs during the 2013 taper-tantrum episode}

This section provides an overview of the taper-tantrum episode of 2013, presents new evidence on the drivers of EME differentiation for the entire duration of the episode, and discusses the timing and persistence of differentiation within sub-intervals of the episode itself.

\subsection{Overview of the episode}

Market participants shifted their expectation for the Federal Reserve's asset purchases program following former Chairman Bernanke's testimony to the Congress on May 22. The testimony heightened perceptions that the Federal Reserve would soon begin tapering its LSAPs and thus lessen the amount of monetary stimulus it was putting into the economy through its unconventional monetary policies. This shift in market expectations led to sharp movements in U.S. and global financial markets, including a large sell-off of EME assets by international investors, causing large depreciations of currencies, increases in bond yields, EMBI spreads, and CDS spreads, as well as declines in equity markets. As shown in table 1, for the median EME in our sample, the dollar exchange rate depreciated 9 percent, sovereign bond yields rose almost 2 percentage points, the EMBI and CDS spreads each rose 0.5 percentage point, and the stock market fell 5 percent from April to August. In response, central banks in some EMEs intervened in the foreign exchange markets to curb depreciation pressures, which resulted in losses of foreign exchange reserves, and also, in some cases, raised policy rates to discourage capital flight. The stress episode persisted for much of the summer, until the Federal Reserve chose not to reduce the size of its asset purchases at the September 2013 Federal Open Market Committee meeting. Thus, we date the taper tantrum episode from May to August and compute the change in financial indicators relative to April, consistent with the literature.

Although most financial markets in EMEs were negatively affected during the taper tantrum, there was wide dispersion in the financial performance across EMEs, as shown by the histograms 
in figure 1. As can be seen in panel 1, although most EME currencies depreciated between 5 and 10 percent, the extent of depreciation did vary quite a bit, with some hardly depreciating at all, while others depreciated more than 15 percent. The use of foreign exchange rate intervention and the response of policy rates also appeared to vary across EMEs (panels 2 and 3, respectively). The heterogeneous response is also apparent in the exchange rate pressure index that combines changes in the exchange rate and foreign exchange reserves (panel 4). Similarly, the increases in bond yields, EMBI spreads, and CDS spreads varied quite a bit across EMEs, as did the declines in equity markets (panels 6-9).

With U.S. interest rates expected to rise, some effect on the EMEs was to be expected for several reasons. For example, rising U.S. rates encourage investors to shift their holdings toward U.S. assets. At the same time, investors may withdraw funds during risk-off episodes especially from those EMEs perceived to be more risky. Indeed, although the movements in most EME financial markets were sizable, investors did not appear to withdraw funds indiscriminately from all EMEs en masse, as shown in figure 1. Therefore, we next turn to the question of whether the varied response of EME financial markets during the taper tantrum episode was systematically related to their economic fundamentals.

\subsection{Differentiation across EMEs during the 2013 stress episode as a whole}

As a first cut to examining this issue, we present some scatter plots capturing bivariate relationships. Figure 2 plots exchange rate depreciations across EMEs during the episode (on the vertical axis) against six potential variables (on the horizontal axis in the different panels) that investors may care about when assessing a country's macroeconomic fundamentals. The figure suggests that the EMEs whose currencies depreciated by more also had larger current account deficits as a share of GDP (panel 1), less reserves-to-GDP (panel 2), more short-term external debt as a share of reserves (panel 3), higher gross government debt ratios (panel 4), and higher average inflation over the past few years (panel 5). The only variable among the ones we show that did not seem to affect financial market performance across EMEs is the runup in bank credit to the private sector as a ratio to GDP (panel 6).

Figure 3 does a similar exercise of linking individual macroeconomic variables to the performance of bond markets, specifically the rise in local currency bond yields during the taper tantrum. The results obtained are generally consistent with those found in figure 2. Bond yield increases were 
greater in economies with greater current account deficits, less reserves, higher short-term debt, and higher average inflation. However, the gross government debt position and, again, the runup in credit to the private sector were not correlated with changes in bond yields.

To further understand the drivers of the heterogeneous performance of EME financial markets, we estimate equation (1) using explanatory variables from the three categories described in section 2, that is, first, those describing the strength of macroeconomic fundamentals, the growth outlook, and the policy framework; second, those relevant for the "more-in-more-out" hypothesis; and third, those describing the structure of financial markets.

\subsubsection{The role of macroeconomic fundamentals}

We find that macroeconomic fundamentals were important drivers of the heterogeneous performance of EME financial markets during the taper tantrum episode, as was suggested by the scatter plots shown earlier. In tables 2 through 4, four of the six variables considered to describe the strength of macroeconomic fundamentals (that is, current account deficits, short-term external debt, government debt, and credit growth) are statistically significant in explaining the behavior of EME financial indicators.

As shown in table 2 (column 1), the EMEs with larger current account deficits and higher gross government debt suffered more severe currency depreciations relative to the dollar. All else equal, a 1 percentage-point higher current account deficit (or stock of government debt) relative to GDP was associated with 0.8 percentage point (or 0.2 percentage point) greater depreciation. Similarly, in table 3 (columns 1 and 7), the EMEs with greater short-term external debt suffered larger increases in bond yields, while the EMEs with faster previous runups in bank credit to the private sector suffered greater declines in equity prices during the episode; an additional 10 percentage points in short-term external debt relative to reserves implied 20 basis points larger increases in bond yields and an additional 1 percentage-point previous increase in bank credit relative to GDP led to 0.4 percentage point greater declines in equity prices during the event.

Unsurprisingly, not all of the six macroeconomic variables are statistically significant in explaining the behavior of each financial indicator. Some macroeconomic characteristics should be more relevant for certain types of financial assets than others. In addition, while the coefficients tend to have the expected signs, their statistical significance is likely constrained by the limited degrees of freedom in multivariate cross-sectional regressions with a relatively small sample and by some likely 
interdependence between the variables. For example, although the scatter plots in figure 2 suggest that five of the six macroeconomic variables affected the extent of exchange rate depreciation during the stress episode, only two of these variables (the current account and government debt) are statistically significant in the multivariate regression in table 2 (column 1). Also, while the current account deficit is statistically significant in bivariate regressions for the increase in EMBI and CDS spreads (not shown), it is not statistically significant in the multivariate regressions in table 4 (columns 1 and 7 ).

However, given that each of the six macroeconomic variables has a role in explaining some aspect of financial performance - in either bivariate or multivariate regressions - in what follows we will consider them jointly in our baseline assessment of the link between macroeconomic fundamentals and differentiation across EMEs financial markets during the taper-tantrum episode.

\subsubsection{The vulnerability index}

To better understand the determinants of financial market performance, we build an index of EME vulnerabilities that summarizes the relative strength of EMEs' macroeconomic fundamentals based on the six variables discussed in section 2, given their importance in shaping the financial market responses. The vulnerability index has the advantage of aggregating the information embedded in multiple macroeconomic variables while addressing the problem of limited degrees of freedom in our multivariate regressions.

To construct the index, we first rank the EMEs relative to each other according to each variable, from lowest vulnerability to highest vulnerability. We then take the average ranking of a country across the six variables to obtain the value of the index for each EME, with higher values representing higher vulnerability. It is important to note that this index represents relative vulnerabilities across EMEs at a point in time and not the absolute levels of vulnerabilities.

Simple estimates from univariate regressions show positive and statistically significant relationships between the vulnerability index as the sole explanatory variable and, alternatively, as dependent variable, the exchange rate depreciation (table 2, column 2), changes in the depreciation pressure index (table 2, column 8), and the increase in local currency bond yields (table 3, column 2). Notably, there are also positive and statistically significant links between the vulnerability index and the increases in the EMBI spreads and CDS spreads (table 4, columns 2 and 8), even though the individual explanatory variables that comprise the index were not statistically signifi- 
cant as determinants of financial performance. However, we do not find a statistically significant link between the vulnerability index and changes in stock prices (table 3, column 8).

\subsubsection{The role of other variables}

While using the EME vulnerability index to summarize the strength of macroeconomic fundamentals, we also explore the role of additional variables in explaining the heterogeneous response of EME financial markets during the taper-tantrum episode. ${ }^{4}$

First, we find some evidence that the performance of EME financial markets was linked to changes in EMEs' growth outlook prior to the episode, which recall is measured as revisions to the Consensus growth outlook for 2013 done between January and May of the same year. However, this evidence is limited in that it applies only to bond yields and EMBI spreads (see column 3 of tables 3 and 4). In addition, we find very limited evidence that the EMEs with inflation targeting regimes or floating exchange rate regimes suffered less deterioration in financial markets than otherwise (see tables 2 through 4, columns 3 and 9).

Second, controlling for the influence of macroeconomic fundamentals, we also find evidence to support the "more-in-more-out" hypothesis for exchange rates and bond yields-that is, the EMEs that received more capital inflows or experienced more exchange rate appreciation prior to the episode suffered greater deteriorations in financial conditions during the episode itself. As shown in table 2, countries that received more private gross inflows (column 4) or had more real effective appreciation previously (column 5) also experienced more depreciation during the episode. In table 3 (column 5), countries that experienced more appreciation previously also suffered greater increases in bond yields during the episode. ${ }^{5}$ All in all, the results confirm that, although the volatility of capital inflows during boom-bust cycles may have weighed on the EME financial markets during the taper tantrum, those countries with stronger fundamentals were better prepared to sustain the financial turbulence brought by the episode.

Third, while controlling for macroeconomic fundamentals, the structure of financial markets seems to matter. Those EMEs with greater capital account openness suffered larger increases in bond yields (table 3, column 6) and also greater declines in the stock market index during the

\footnotetext{
${ }^{4}$ For stock market indexes, for which the vulnerability index is not statistically significant, we use the runup in bank credit instead of the vulnerability index as a control when testing the relevance of the additional variables examined in this section (table 3, columns 9-12).

${ }^{5}$ In table 3, column 5, when using the vulnerability index instead of short-term external debt, the coefficient estimate for real effective appreciation maintains its sign but loses statistical significance.
} 
episode (table 3, column 12), results that lend indirect support to the "more-in-more-out" hypothesis. Also, the EMEs with greater market capitalization suffered more exchange rate depreciation (table 2, column 6), while those with greater foreign participation in equity markets suffered larger increases in EMBI spreads during the episode (table 4, column 6). ${ }^{6}$

Notwithstanding the role of these other factors, we find our relative vulnerability index across the EMEs to be a very robust summary statistic explaining heterogeneous responses across EMEs during the taper tantrum. In the univariate specifications in which the vulnerability index is statistically significant (see tables 2 through 4, columns 2 and 8), the vulnerability index explains more of the variation of the dependent variable than any of the other explanatory variables taken individually. For example, the vulnerability index explains 65 percent of the variation in exchange rate depreciations during the taper tantrum episode (table 2, column 2). In contrast, the cumulated gross capital inflows alone (not shown) explain 29 percent of the variation, foreign participation explains only 14 percent, and the growth forecast revision explains a mere 2 percent. $^{7}$

\subsection{Timing and persistence of differentiation across EMEs within the 2013 episode}

We next explore the timing and persistence of differentiation among EMEs during the episode of financial stress that started in May 2013. To this end, we use two measures of financial performance, one cumulative and another one incremental. First, for the cumulative measure, we keep the basis of comparison fixed in April 2013 and take windows of varying lengths (in months) up to December (that is, windows that end successively between May and December 2013). We compute the financial performance of EMEs for each of these windows and explore the link with the vulnerability index described earlier. Second, for the incremental measure of financial performance, we take the monthto-month changes in EME financial indicators for the entire duration of the stress episode (that is, the first window is April to May of 2013; the last window is November to December 2013).

The results suggest that the differentiation across EMEs started relatively early in the stress period and persisted even after the episode ended, although the degree of differentiation eased in the

\footnotetext{
${ }^{6}$ In table 4, column 6 , when using the vulnerability index instead of the current account, the coefficient estimate for foreign participation maintains its sign but loses statistical significance.

${ }^{7}$ In general, the vulnerability index also explains more of the variation in dependent variables than each of the six variables used to construct the index. The exception applies to the change in bond yields as the dependent variable (table 3, column 2), for which the vulnerability index explains a bit less than either the current account or the short-term external debt taken individually.
} 
later months of the episode. In table 5 (column 1 of either the top or bottom panel), the results show a positive and statistically significant link between the depreciation pressure index (the dependent variable) and the vulnerability index (the explanatory variable) even over the end-April to endMay period, suggesting that differentiation set in early when the taper-tantrum episode began in late May. Computing the depreciation pressure cumulated over windows of different lengths in the top panel, the differentiation among EMEs according to the vulnerability index persisted throughout the stress period. For the incremental depreciation pressure in the bottom panel, most of the differentiation occurred in May, June, and August (columns 1, 2, and 4). However, some of the differentiation was reversed later in October (column 6), when the coefficient switches signs, suggesting that the most vulnerable EMEs retraced some of their previous depreciations or declines in reserves as stress in global financial markets eased.

Similarly, as shown in table 6 , there was a positive and statistically significant link between the cumulative increase in local currency bond yields (the dependent variable) and the vulnerability index starting in July 2013, and the link persisted until at least December (top panel). For the month-to-month increase in yields (bottom panel), most of the differentiation occurred in June, July, and August (columns 2, 3, and 4), with a renewed bout in December (column 8).

In sum, these results are consistent with the interpretation that investors adjusted their portfolio exposure by differentiating against the relatively more vulnerable EMEs and did not fully reverse this adjustment several months after the stress episode ended.

\section{Differentiation across EMEs during past stress episodes}

In this section, we assess whether the differentiation across EMEs according to macroeconomic fundamentals was a development specific to the 2013 taper tantrum episode or, whether any differentiation across EMEs during past episodes of financial stress is also explained well by differences in their vulnerabilities.

To address this question, we first develop a methodology to identify historical events of financial stress going back to the 1990s. Second, taking the identified start and end dates for each historical event as given, we construct the EME vulnerability index for the year prior to each event (using the methodology in section 3.2.2), and also construct measures of financial performance during the event using the month prior to the start date as the basis of comparison. Finally, we examine how 
the link between macroeconomic fundamentals and financial performance has evolved over time.

\subsection{Identification of past stress episodes}

To identify stress events, we look for outsized movements in three broad indicators that characterize financial markets in the EMEs. Specifically, we search for: (1) unusually large increases in VIX, which serves as a proxy for perceived risk and global risk aversion; (2) unusually large depreciations in an aggregate index of EME currencies against the dollar; and (3) unusually large declines in the MSCI equity index for the EMEs. ${ }^{8}$ Generally, we define an episode of financial stress occurring when at least two of the three indicators display unusually large movements over the same period.

Figure 4 shows the three aggregate financial indicators for the EMEs at the weekly frequency starting in 1990. To identify unusually large movements in each of the three indicators along with the corresponding peak and trough dates, we use the following algorithm. First, for the VIX, we compute its deviations from a Hodrick-Prescott trend fitted over the interval from 1990 to 2013. To identify possible episodes and their duration, we select all consecutive observations in which the VIX was at least two standard deviations above the trend; when these observations are immediately preceded or followed by values that were at least one standard deviation above the trend, we include these other observations in the event as well. The first and last dates of each VIX-determined event are considered as intervals for the episodes.

Second, for the aggregate index of EME currencies, we compute the percent change in the index relative to the maximum value recorded over the previous six months, and select instances when the depreciation was 5 percent or more. We select the trough as the end date (that is, the week of maximum depreciation relative to the six-month maximum), and the maximum as the start date for each possible event.

Third, for the MSCI stock market index, we also compute the percent change in the index relative to the maximum recorded over the previous six months, and focus on instances when the decline was 10 percent or more. As in the case of exchange rates, we select the trough as the end date (that is, the week of maximum decline), and the maximum as the start date for each possible event. Finally, we consider the dates of events indicated by each of the three measures, and focus on instances in which at least two of the three indicators point to overlapping events.

\footnotetext{
${ }^{8}$ Specifically, we use the Federal Reserve Board's U.S. trade-weighted aggregate nominal index of the dollar against a number of EMEs.
} 
Based on this methodology, we identify 13 episodes of financial stress in the EMEs going back to 1990, which are illustrated by the shaded areas in figure 4 (either shaded grey or blue). Out of these, we judgmentally choose a sub-set of seven events (that is, those in blue) that are associated with well-known episodes of financial stress, including: (1) the Mexican crisis, from September 1994 to March 1995; (2) the Asian crisis, from July 1997 to January 1998; (3) the Russian crisis, from August to November 1998; (4) the aftermath of the Argentine crisis, from April to October 2002; (5) the GFC, from September 2008 to February 2009; (6) the European sovereign debt crisis, from July to December of 2011; and (7) the 2013 taper tantrum. ${ }^{9}$

\subsection{Did economic fundamentals matter during past stress episodes?}

We estimate univariate regressions based on equation (1) for the seven historical episodes during which EME financial conditions deteriorated significantly. The sole explanatory variable, the vulnerability index, is computed based on the six macroeconomic variables discussed in section 2, using values for the year preceding each stress episode. The dependent variable, the depreciation pressure index, is based on changes in exchange rates and losses in foreign exchange reserves measured from the month prior to the start date to the end month of each event. Given the shifts in exchange rate regimes over time, it is important that we use the depreciation pressure index rather than just the exchange rate depreciation to measure financial performance during the 1990s. For instance, the EMEs with heavily managed exchange rate regimes may have experienced less depreciation during a stress episode (that is, barring a devaluation), which would have falsely indicated resilience of their currencies; the depreciation pressure index solves this problem by also taking into account the loss in reserves required to maintain the managed float during a crisis episode. Finally, for each episode, we exclude the EMEs at the epicenter of each crisis given their status as outliers (that is, Mexico in 1994, Indonesia, Malaysia, the Philippines, South Korea, and Thailand in 1997, Russia in 1998, and Argentina and Uruguay in 2001).

The results for the depreciation pressure index are presented in figure 5 and table 7 (top panel). Figure 5 shows scatter plots between the vulnerability index (on the horizontal axis) and the depreciation pressure index (on the vertical axis) for each of the seven historical episodes along with the regression lines, while table 7 provides more detailed results for the corresponding univariate re-

\footnotetext{
${ }^{9}$ We include the taper-tantrum episode again with this endogenous dating of the episode, which picks out May to August as the dates for the episode, consistent with what we chose in section 3.1.
} 
gressions. From figure 5, it appears that while there was some heterogeneity in the financial market performances during the EME crises of the 1990s and the early 2000s, the ability of macroeconomic fundamentals (as measured by our relative vulnerability index) to explain this heterogeneity was weak (panel 1 thourgh 4). However, judging from the increasingly close alignment between vulnerability and depreciation pressure, differentiation appears to begin with the GFC in 2008-09, then strengthens during the European sovereign debt crisis in 2011, and strengthens even more during the 2013 taper tantrum (panel 5 through 7). The results in table 7 (top panel) confirm this: the vulnerability index is not statistically significant and the R-squared values are very low for the Mexican crisis in 1994 through 1995 (column 1), the Asian crisis in 1997 (column 2), the Russian crisis in 1998 (column 3), and the Argentine crisis in 2002 (column 4). However, the vulnerability index became significant during the GFC in 2008 (column 4), and the coefficient and R-squared values increase for the European sovereign crisis in 2011 (column 6), and even more for the taper tantrum in 2013 (column 7).

Regarding the link between the vulnerability index and changes in stock market prices during each stress episode (figure 6), we see little evidence of differentiation during the past episodes of financial stress, just as we found no evidence for the summer of 2013. The corresponding coefficients in table 7 (the bottom panel) are generally not statistically significant. Finally, we could not perform a similar exercise for the increase in bond yields, EMBI spreads, and CDS spreads due to the limited availability of historical data.

In sum, it is noteworthy that macroeconomic fundamentals have gained increasing importance in recent years in explaining differences in financial pressures across EMEs during episodes of heightened financial stress. However, more research is needed to fully understand the factors explaining this apparent shift in behavior. There are at least two main hypotheses. On one hand, the improvement in macroeconomic fundamentals (to varying degrees across EMEs) combined with a better knowledge (perhaps made easier by technological advances and improvements in data quality) of individual EMEs' characteristics could have changed the extent to which investors view EMEs as representing a single asset class. On the other hand, the shifting nature of the sources of the shocks that triggered stress events could also be a potential contributing factor to the rise in differentiation over time. While the financial crises before the GFC - when we find little evidence of any differentiation by investors being related to economic fundamentals - had originated to an important extent in the EMEs themselves, the latest three episodes of financial stress - when 
differentiation by investors could be explained well by differences in economic fundamentals - were more obviously triggered by events originating in the advanced economies. ${ }^{10}$ As such, it is an issue for future research whether the EMEs' remoteness from the origins of the financial stress lends itself to investors discriminating more across EMEs according to their economic fundamentals.

\section{Conclusion}

The taper-tantrum episode was triggered by a shift in May 2013 in market perceptions regarding the prospects for LSAPs by the Federal Reserve. It is important to understand the implications for the global economy, and particularly for the EMEs, that arise from evolving expectations of monetary policy actions by the Federal Reserve and other major advanced-economy central banks.

In this study, we documented the deterioration in the financial conditions of EMEs during the 2013 taper-tantrum episode. One intriguing aspect of this episode is that the response of EME financial markets was heterogeneous. Our study explored the role of country-specific characteristics, especially countries' macroeconomic fundamentals, in explaining the heterogeneous response. Looking at performance across the whole episode, our results indicate that there was differentiation by investors across EMEs explained in large part by variation in the strength of their economic fundamentals, and that the differentiation began early in the episode and persisted throughout it. This result holds whether we use different individual variables to measure economic fundamentals, or aggregate them to come up with a single index or relative vulnerabilities across EMEs. Taken at face value, these results suggest that policies to further strengthen economic fundamentals could go a long way to help the EMEs mitigate any disruptive effects from eventual normalization of monetary policy in the advanced economies.

While the strength of economic fundamentals was the most important factor influencing the deterioration of EME financial markets during the taper-tantrum episode, we find that other factors were at play as well. Controlling for economic fundamentals, financial market performance during the taper tantrum appeared to be weaker in those EMEs that had earlier received the largest gross private inflows of capital and had the greatest currency appreciations. For the performance of bond

\footnotetext{
${ }^{10}$ Of course, as some observers have noted, even in the well-known EME crises such as those in the 1990s, shocks outside of the EMEs themselves could sometimes act as one of the trigger points for the start of the crisis or for making it worse. Often these crises involved heightened country-specific domestic vulnerabilities, including over-borrowing in an environment of fixed exchange regimes, and, in this setting, external developments, such as a rise in global interest rates, contributed to their crises.
} 
yields and credit spreads, revisions to the growth outlook also seemed to matter.

We further explored whether any heterogeneous responses of EME financial markets during past episodes of severe EME-wide financial stress over the past 20 years could also be explained by differences in economic fundamentals across EMEs. For EME financial crises of the 1990s and early 2000s, we find little evidence that investors discriminated across EMEs significantly according to the strengths of their fundamentals. However, our results do suggest that differentiation among EMEs based on economic fundamentals has occurred since the mid-2000s, beginning with the global financial crisis in 2008 and progressively increasing over time through the European debt crisis of 2011 and through the 2013 taper-tantrum episode.

The interpretation of the results that differentiation by investors across EMEs can be explained well by differences in economic fundamentals after the mid-2000s but not before is not clear-cut, however. One interpretation could be that, prior to the early 2000s, the EMEs were viewed as a single asset class by international investors due to a combination of still-developing policy frameworks and less knowledge of characteristics of and differences across individual EMEs. As policy frameworks matured (to varying degrees across EMEs) and as advancement of technology facilitated timely and less costly access to information and data about particular EMEs, it became natural for investors not to more or less put all EMEs in one basket, but to look more closely at differences in their relative vulnerabilities. But another interpretation may lie in the idea that the factors that have led to financial stresses in the EMEs have been different since the mid-2000s compared with the period before. In particular, there is a sense that the origins of the shocks causing periods of severe EME-wide financial stresses since the mid-2000s have been further removed from the EMEs themselves compared with the EME crises of the 1990s and early 2000s. The source of the shock may matter in how much investors differentiate across EMEs based on their economic fundamentals. 


\section{References}

Aizenman Joshua, Mahir Binici, and Michael M. Hutchison, 2014. "The Transmission of Federal Reserve Tapering News to Emerging Financial Markets." Cambridge, Mass: NBER Working Paper No. 19980.

Bowman, David, Juan Miguel Londono Yarce, and Horacio Sapriza, 2014. "U.S. Unconventional Monetary Policy and Transmission to Emerging Market Economies," International Finance Discussion Paper No. 1109, Board of Governors of the Federal Reserve System, June.

Calvo, Guillermo, and Enrique Mendoza, (2001). "Rational Herd Behavior and the Globalization of the Securities Market." Journal of International Economics.

Chinn, Menzie and Hiro, Ito (2006). "A New Measure of Financial Openness," Journal of Comparative Policy Analysis 10(3). September 2008: pp. 307-20.

Dornbusch, Rudiger, Yung Chul Park, and Stijn Claessens, (2000). "Contagion: Understanding How It Spreads." The World Bank Research Observer, vol. 15, no. 2, pp. 177-97.

Eichengreen Barry and Poonam Gupta, (2014). "Tapering Talk: The Impact of Expectations of Reduced Federal Reserve Security Purchases on Emerging Markets" Policy Research Working Paper 6754. Washington: World Bank, January.

Eichengreen, Barry, Andrew Rose and Charles Wyplosz, 1995. "Exchange Market Mayhem: The Antecedents and Aftermath of Speculative Attacks," Economic Policy, vol 10, issue 21, pp. 249312.

Ilzetzki, Ethan and Reinhart, Carmen and Rogoff, Kenneth (2011). "Exchange Rate Arrangements Entering the 21st Century: Which Anchor Will Hold?" mimeo, University of Maryland and Harvard University.

Prachi Mishra, Kenji Moriyama, Papa N'Diaye, and Lam Nguyen, (2014). "Impact of Fed Tapering Announcements on Emerging Markets." IMF Working Paper 14/109. Washington: International Monetary Fund, June. 
Sahay, Ratna, Vivek Arora, Thanos Arvanitis, Hamid Faruqee, Papa N'Diaye, Tommaso ManciniGriffoli, and an IMF Team, 2014. "Emerging Market Volatility: Lessons from the Taper Tantrum," IMF Staff Discussion Note SDN 14/09, September 2014. 
Table 1: Summary statistics for the 2013 taper-tantrum episode

\begin{tabular}{|c|c|c|c|c|c|c|c|}
\hline Variable: & Obs & Mean & Median & St.Dev. & Min & Max & Source \\
\hline \multicolumn{8}{|l|}{ Dependent variables: } \\
\hline Exchange rate depreciation (\%) & 20 & 9.4 & 8.7 & 6.2 & -0.8 & 22.8 & IMF's IFS database \\
\hline Depreciation pressure index & 20 & 1.8 & 1.6 & 1.2 & -0.2 & 4.2 & Authors' calculations \\
\hline Depreciation pressure index 2 & 20 & 1.8 & 1.5 & 1.6 & -0.3 & 5.5 & Authors' calculations \\
\hline Change in local currency bond yields (ppt) & 14 & 1.2 & 1.9 & 0.8 & 0.3 & 2.7 & Bloomberg \\
\hline Change in stock market index (\%) & 17 & -4.6 & -5.1 & 7.3 & -15.0 & 9.7 & Bloomberg \\
\hline Change in EMBI spreads (ppt) & 15 & 0.5 & 0.5 & 0.3 & -0.1 & 1.1 & JP Morgan's EMBI Global database \\
\hline Change in CDS spreads (ppt) & 14 & 0.5 & 0.4 & 0.3 & 0.0 & 1.0 & Markit \\
\hline \multicolumn{8}{|l|}{ Memo: } \\
\hline Change in reserves $(\%)$ & 20 & -3.1 & -2.6 & 7.3 & -25.0 & 12.5 & IMF's IFS database \\
\hline Change in policy rates (ppt) & 20 & 0.0 & 0.0 & 0.6 & -1.4 & 1.5 & Bloomberg, Haver \\
\hline \multicolumn{8}{|l|}{ Macro fundamentals and policy variables: } \\
\hline Current account/GDP 2012 & 20 & -0.6 & -1.7 & 4.4 & -6.2 & 10.7 & IMF's WEO database \\
\hline Reserves/GDP 2012 & 20 & 24.8 & 17.4 & 18.7 & 4.5 & 84.8 & Haver, IMF's IFS database \\
\hline Short-term ext. debt/reserves 2012 & 20 & 37.5 & 35.4 & 19.6 & 12.1 & 87.5 & Joint External Hub Database (BIS-IMF-OECD-WB) \\
\hline Gov debt/GDP 2012 & 20 & 39.3 & 40.7 & 17.8 & 12.0 & 68.2 & IMF's Historical Debt and WEO databases \\
\hline Inflation, annual, 2010-12 average & 20 & 5.3 & 4.4 & 2.9 & 1.4 & 11.8 & Haver \\
\hline Bank credit/GDP 5-year change, 2012 & 20 & 9.7 & 7.6 & 11.3 & -11.7 & 26.2 & IMF's IFS database \\
\hline Vulnerability index 2012 & 20 & 23.0 & 23.5 & 6.7 & 11.8 & 36.0 & Authors' calculations \\
\hline Growth forecast 2013 revision, Consensus & 20 & 0.1 & -0.1 & 0.6 & -0.6 & 2.2 & Consensus growth forecast \\
\hline Dummy, inflation targeter & 19 & 0.6 & 1.0 & 0.5 & 0.0 & 1.0 & IMF's Exchange Rate Classification \\
\hline Dummy, XR floater & 19 & 0.1 & 0.0 & 0.3 & 0.0 & 1.0 & IMF's Exchange Rate Classification \\
\hline \multicolumn{8}{|l|}{ More-in-more-out variables: } \\
\hline Gross inflows/GDP, cumul. 2010-12 & 19 & 3.4 & 2.4 & 2.9 & -0.3 & 8.5 & Haver \\
\hline REER appreciation, average $2009-12$ & 20 & 2.8 & 2.5 & 2.7 & -2.0 & 8.3 & Federal Reserve Board \\
\hline \multicolumn{8}{|l|}{ Financial market structure: } \\
\hline Market cap/GDP 2011 & 19 & 55.2 & 46.0 & 39.6 & 0.0 & 137.0 & WB's WDI database \\
\hline Foreign participation/market cap 2011 & 18 & 13.8 & 14.2 & 6.8 & 3.4 & 24.5 & IMF's IFS database, WB's WDI database \\
\hline Capital account openess 2011 & 19 & 0.0 & -0.1 & 1.2 & -1.2 & 2.4 & Chinn-Ito index database \\
\hline
\end{tabular}

Note: Changes in dependent variables are computed from April to August 2013. Exchange rates are expressed as units of local currency to the dollar, so that positive changes indicate depreciation. The depreciation pressure index is based on currency depreciation and losses in foreign exchange reserves, with larger values indicating stronger depreciation pressure. Alternatively, the depreciation pressure index 2 is based on currency depreciation, losses in foreign exchange reserves, and policy rate increases, with larger values indicating stronger depreciation pressure. The sample includes Argentina, Brazil, China, Chile, Colombia, Indonesia, India, South Korea, Malaysia, Mexico, Peru, Paraguay, the Philippines, Pakistan, Russia, South Africa, Taiwan, Thailand, Turkey, and Uruguay. 
Table 2: Determinants of exchange rate depreciation and the depreciation pressure index

\begin{tabular}{|c|c|c|c|c|c|c|c|c|c|c|c|c|c|}
\hline & $(1)$ & $(2)$ & $(3)$ & $(4)$ & $(5)$ & $(6)$ & (7) & $(8)$ & (9) & $(10)$ & $(11)$ & $(12)$ \\
\hline & & \multicolumn{6}{|c|}{ Exchange rate depreciation, April-August 2013 (\%) } & \multicolumn{6}{|c|}{ Depreciation pressure index, April-August 2013} \\
\hline \multirow{10}{*}{$\begin{array}{l}\text { Macro } \\
\text { fundamentals } \\
\text { and policy }\end{array}$} & CA/GDP 2012 & $\begin{array}{c}-0.82^{* *} \\
(0.37)\end{array}$ & & & & & & \multirow{15}{*}{$\begin{array}{c}-0.084 \\
(0.082) \\
-0.0051 \\
(0.020) \\
0.0056 \\
(0.014) \\
0.023 \\
(0.014) \\
0.15 \\
(0.099) \\
0.0030 \\
(0.020)\end{array}$} & & & & & \\
\hline & Reserves/GDP 2012 & $\begin{array}{c}0.039 \\
(0.089)\end{array}$ & & & & & & & & & & & \\
\hline & Short-term ext. debt/reserves 2012 & $\begin{array}{c}0.069 \\
(0.062)\end{array}$ & & & & & & & & & & & \\
\hline & Gov debt/GDP 2012 & $\begin{array}{c}0.16^{* *} \\
(0.061)\end{array}$ & & & & & & & & & & & \\
\hline & Inflation, average $2010-12$ & $\begin{array}{c}0.13 \\
(0.44)\end{array}$ & & & & & & & & & & & \\
\hline & Bank credit/GDP 5-year change, 2012 & 0.059 & & & & & & & & & & & \\
\hline & Vulnerability index 2012 & & $\begin{array}{c}0.74^{* * *} \\
(0.13)\end{array}$ & $\begin{array}{c}0.75^{\star * *} \\
(0.18)\end{array}$ & $\begin{array}{c}0.66^{* * *} \\
(0.12)\end{array}$ & $\begin{array}{c}0.76^{* * *} \\
(0.12)\end{array}$ & $\begin{array}{c}0.78^{* * *} \\
(0.14)\end{array}$ & & $\begin{array}{l}0.14^{* * *} \\
(0.027)\end{array}$ & $\begin{array}{l}0.14^{* * *} \\
(0.037)\end{array}$ & $\begin{array}{l}0.14^{* * *} \\
(0.031)\end{array}$ & $\begin{array}{l}0.14^{* * *} \\
(0.028)\end{array}$ & $\begin{array}{l}0.14^{* * *} \\
(0.037)\end{array}$ \\
\hline & Growth forecast 2013 revision & & & $\begin{array}{c}1.03 \\
(1.66)\end{array}$ & & & & & & $\begin{array}{c}0.11 \\
(0.35)\end{array}$ & & & \\
\hline & Dummy, inflation targeter & & & $\begin{array}{c}0.97 \\
(2.12)\end{array}$ & & & & & & $\begin{array}{r}-0.036 \\
(0.45)\end{array}$ & & & \\
\hline & Dummy, XR floater & & & $\begin{array}{l}-0.98 \\
(3.68)\end{array}$ & & & & & & $\begin{array}{r}-0.089 \\
(0.78)\end{array}$ & & & \\
\hline \multirow[t]{2}{*}{$\begin{array}{l}\text { More-in- } \\
\text { more-out }\end{array}$} & Gross inflows/GDP, cumul. 2010-12 & & & & $\begin{array}{c}0.84^{* * *} \\
(0.26)\end{array}$ & & & & & & \multirow[t]{2}{*}{$\begin{array}{c}0.043 \\
(0.068)\end{array}$} & & \\
\hline & REER appreciation, average 2009-12 & & & & & $\begin{array}{l}0.55^{*} \\
(0.30)\end{array}$ & & & & & & $\begin{array}{l}0.0079 \\
(0.069)\end{array}$ & \\
\hline \multirow[t]{5}{*}{$\begin{array}{l}\text { Financial } \\
\text { structure }\end{array}$} & Market cap/GDP, 2011 & & & & & & $\begin{array}{c}0.048^{*} \\
(0.024)\end{array}$ & & & & & & $\begin{array}{c}0.0037 \\
(0.0062)\end{array}$ \\
\hline & Foreign participation/market cap, 2011 & & & & & & $\begin{array}{c}0.13 \\
(0.12)\end{array}$ & & & & & & $\begin{array}{c}0.014 \\
(0.032)\end{array}$ \\
\hline & Capital account openess & & & & & & $\begin{array}{r}-0.066 \\
(0.75)\end{array}$ & & & & & & $\begin{array}{l}-0.20 \\
(0.19)\end{array}$ \\
\hline & Constant & $\begin{array}{l}-2.39 \\
(4.58)\end{array}$ & $\begin{array}{c}-7.76^{\star \star} \\
(3.12)\end{array}$ & $\begin{array}{l}-8.50^{*} \\
(4.52)\end{array}$ & $\begin{array}{c}-8.65^{\star \star \star} \\
(2.87)\end{array}$ & $\begin{array}{c}-9.67^{* * *} \\
(3.13)\end{array}$ & $\begin{array}{c}-13.5^{\star \star \star} \\
(4.00)\end{array}$ & $\begin{array}{r}-0.022 \\
(1.02)\end{array}$ & $\begin{array}{c}-1.52^{\star *} \\
(0.65)\end{array}$ & $\begin{array}{l}-1.42 \\
(0.95)\end{array}$ & $\begin{array}{c}-1.48^{*} \\
(0.76)\end{array}$ & $\begin{array}{c}-1.55^{\star *} \\
(0.71)\end{array}$ & $\begin{array}{l}-1.91^{*} \\
(1.03)\end{array}$ \\
\hline & R-squared & 0.72 & 0.64 & 0.61 & 0.76 & 0.70 & 0.75 & 0.65 & 0.61 & 0.56 & 0.57 & 0.61 & 0.65 \\
\hline
\end{tabular}

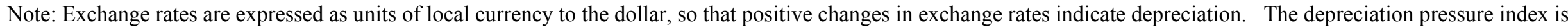

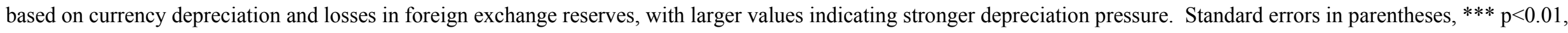
$* * \mathrm{p}<0.05, * \mathrm{p}<0.1$. 
Table 3: Determinants of the increase in bond yields and the decline in stock market prices

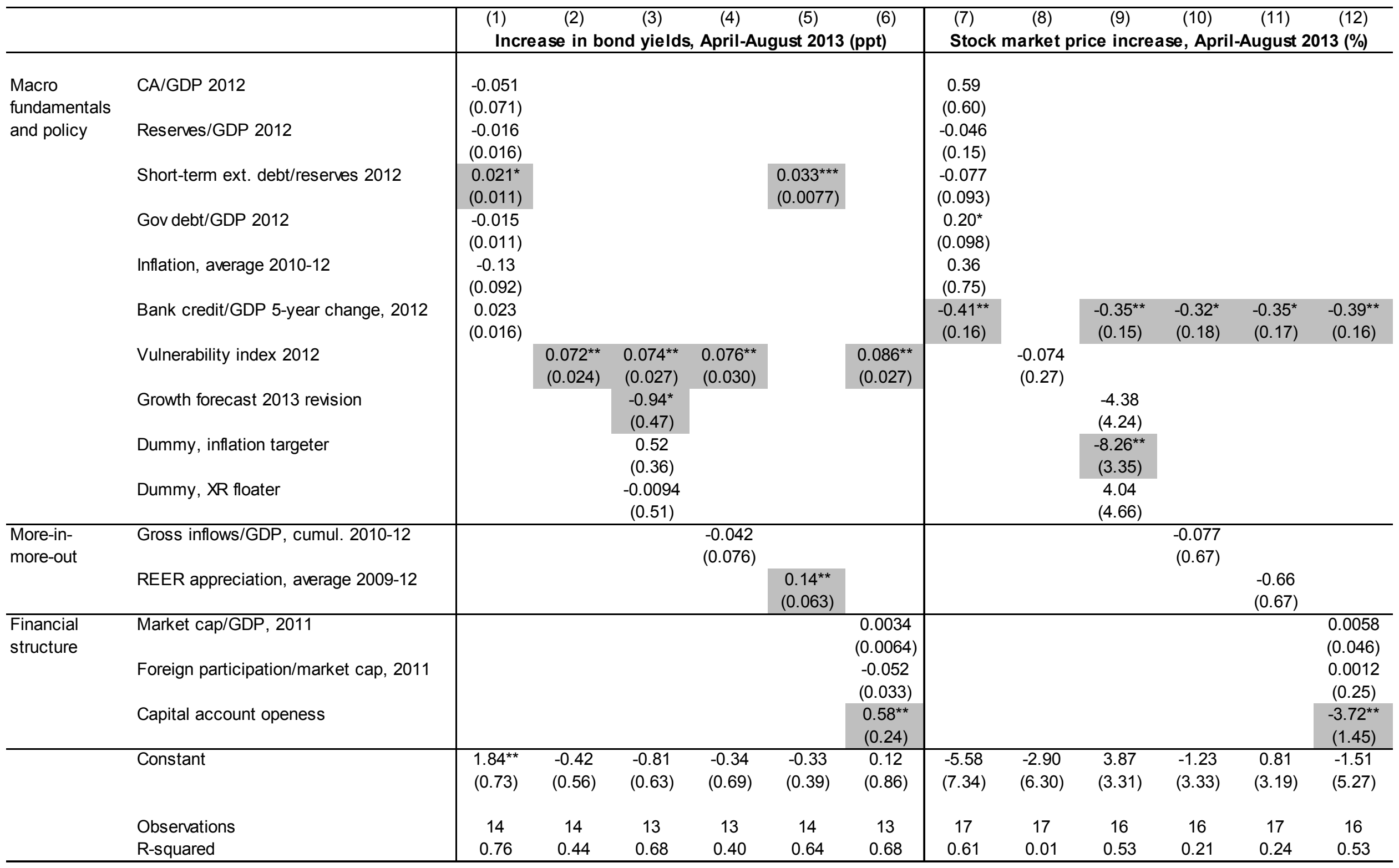

Note: Standard errors in parentheses, ${ }^{* * *} \mathrm{p}<0.01,{ }^{*} * \mathrm{p}<0.05,{ }^{*} \mathrm{p}<0.1$. 
Table 4: Determinants of the increase in EMBI spreads and CDS spreads

\begin{tabular}{|c|c|c|c|c|c|c|c|c|c|c|c|c|c|}
\hline \multirow{2}{*}{$\begin{array}{l} \\
\text { Macro } \\
\text { fundamentals } \\
\text { and policy }\end{array}$} & & \multicolumn{6}{|c|}{ Increase in EMBI spreads, April-August 2013 (ppt) } & & \multicolumn{5}{|c|}{ Increase in CDS spreads, April-August 2013 (ppt) } \\
\hline & $\begin{array}{l}\text { CA/GDP } 2012 \\
\text { Reserves/GDP } 2012 \\
\text { Short-term ext. debt/reserves } 2012 \\
\text { Gov debt/GDP } 2012 \\
\text { Inflation, average } 2010-12 \\
\text { Bank credit/GDP 5-year change, } 2012 \\
\text { Vulnerability index } 2012 \\
\text { Growth forecast } 2013 \text { revision } \\
\text { Dummy, inflation targeter } \\
\text { Dummy, XR floater }\end{array}$ & $\begin{array}{c}-0.031 \\
(0.041) \\
-0.0048 \\
(0.011) \\
-0.00018 \\
(0.0064) \\
0.0053 \\
(0.0047) \\
0.033 \\
(0.044) \\
-0.0054 \\
(0.0081)\end{array}$ & $\begin{array}{c}0.034^{* * *} \\
(0.011)\end{array}$ & $\begin{array}{c}0.036^{\star * *} \\
(0.010) \\
-0.20^{*} \\
(0.10)\end{array}$ & $\begin{array}{l}0.033^{* *} \\
(0.012)\end{array}$ & $\begin{array}{l}0.035^{\star *} \\
(0.012)\end{array}$ & $\begin{array}{c}-0.061^{* *} \\
(0.021)\end{array}$ & $\begin{array}{c}-0.034 \\
(0.023) \\
0.0022 \\
(0.0088) \\
0.00026 \\
(0.0039) \\
0.0023 \\
(0.0040) \\
0.079 \\
(0.046) \\
0.00075 \\
(0.0074)\end{array}$ & $\begin{array}{l}0.032^{* * *} \\
(0.0077)\end{array}$ & $\begin{array}{c}0.035^{\star *} \\
(0.011) \\
0.14 \\
(0.17) \\
-0.17 \\
(0.13) \\
0.047 \\
(0.18)\end{array}$ & $\begin{array}{l}0.030^{* * *} \\
(0.0079)\end{array}$ & $\begin{array}{l}0.032^{* * *} \\
(0.0081)\end{array}$ & $\begin{array}{l}0.031^{* * *} \\
(0.0094)\end{array}$ \\
\hline $\begin{array}{l}\text { More-in- } \\
\text { more-out }\end{array}$ & $\begin{array}{l}\text { Gross inflows/GDP, cumul. 2010-12 } \\
\text { REER appreciation, average 2009-12 }\end{array}$ & & & & $\begin{array}{c}0.016 \\
(0.028)\end{array}$ & $\begin{array}{l} \\
0.0091 \\
(0.027)\end{array}$ & & & & & $\begin{array}{c}0.019 \\
(0.018)\end{array}$ & $\begin{array}{l}-0.0055 \\
(0.022)\end{array}$ & \\
\hline $\begin{array}{l}\text { Financial } \\
\text { structure }\end{array}$ & $\begin{array}{l}\text { Market cap/GDP, } 2011 \\
\text { Foreign participation/market cap, } 2011 \\
\text { Capital account openess }\end{array}$ & & & & & & $\begin{array}{c}0.00044 \\
(0.0020) \\
0.022^{*} \\
(0.012) \\
-0.060 \\
(0.073)\end{array}$ & & & & & & $\begin{array}{c}-0.00085 \\
(0.0017) \\
-0.0043 \\
(0.0086) \\
-0.039 \\
(0.050)\end{array}$ \\
\hline & Constant & $\begin{array}{c}0.27 \\
(0.42)\end{array}$ & $\begin{array}{l}-0.31 \\
(0.28)\end{array}$ & $\begin{array}{l}-0.32 \\
(0.25)\end{array}$ & $\begin{array}{l}-0.34 \\
(0.29)\end{array}$ & $\begin{array}{l}-0.35 \\
(0.31)\end{array}$ & $\begin{array}{c}0.10 \\
(0.21)\end{array}$ & $\begin{array}{r}-0.015 \\
(0.42)\end{array}$ & $\begin{array}{l}-0.20 \\
(0.18)\end{array}$ & $\begin{array}{l}-0.15 \\
(0.22)\end{array}$ & $\begin{array}{l}-0.22 \\
(0.18)\end{array}$ & $\begin{array}{l}-0.18 \\
(0.20)\end{array}$ & $\begin{array}{l}-0.061 \\
(0.28)\end{array}$ \\
\hline & $\begin{array}{l}\text { Observations } \\
\text { R-squared }\end{array}$ & $\begin{array}{c}15 \\
0.56\end{array}$ & $\begin{array}{c}15 \\
0.42\end{array}$ & $\begin{array}{c}15 \\
0.56\end{array}$ & $\begin{array}{c}15 \\
0.44\end{array}$ & $\begin{array}{c}15 \\
0.43\end{array}$ & $\begin{array}{c}14 \\
0.64\end{array}$ & $\begin{array}{c}14 \\
0.62\end{array}$ & $\begin{array}{c}14 \\
0.58\end{array}$ & $\begin{array}{c}14 \\
0.66\end{array}$ & $\begin{array}{c}14 \\
0.62\end{array}$ & $\begin{array}{c}14 \\
0.58\end{array}$ & $\begin{array}{c}14 \\
0.62\end{array}$ \\
\hline
\end{tabular}

Note: Standard errors in parentheses, ${ }^{* * *} \mathrm{p}<0.01,{ }^{*} * \mathrm{p}<0.05, * \mathrm{p}<0.1$. 
Table 5: Examination of the April-August 2013 event: the depreciation pressure index

(a) Cumulative stress

\begin{tabular}{lcccccccc}
\hline $\begin{array}{l}\text { Dependent variable: } \\
\text { Depreciation pressure index }\end{array}$ & $\begin{array}{c}(1) \\
\text { Apr-May }\end{array}$ & $\begin{array}{c}(2) \\
\text { Apr-Jun }\end{array}$ & $\begin{array}{c}(3) \\
\text { Apr-Jul }\end{array}$ & $\begin{array}{c}(4) \\
\text { Apr-Aug }\end{array}$ & $\begin{array}{c}(5) \\
\text { Apr-Sep }\end{array}$ & $\begin{array}{c}(6) \\
\text { Apr-Oct }\end{array}$ & $\begin{array}{c}(7) \\
\text { Apr-Nov }\end{array}$ & $\begin{array}{c}(8) \\
\text { Apr-Dec }\end{array}$ \\
\hline Vulnerability index 2012 & & & & & & & & \\
& $0.098^{*}$ & $0.12^{* * *}$ & $0.12^{* * *}$ & $0.14^{* * *}$ & $0.13^{* * *}$ & $0.11^{* * *}$ & $0.10^{* *}$ & $0.10^{* *}$ \\
& $(0.047)$ & $(0.028)$ & $(0.026)$ & $(0.028)$ & $(0.033)$ & $(0.031)$ & $(0.037)$ & $(0.038)$ \\
Observations & & & & & & 18 & 18 & 18 \\
R-squared & 18 & 18 & 18 & 18 & 18 & 18 \\
\hline
\end{tabular}

(b) Incremental stress

\begin{tabular}{lccccccccc}
\hline $\begin{array}{l}\text { Dependent variable: } \\
\text { Depreciation pressure index }\end{array}$ & $\begin{array}{c}(1) \\
\text { Apr-May }\end{array}$ & $\begin{array}{c}(2) \\
\text { May-Jun }\end{array}$ & $\begin{array}{c}(3) \\
\text { Jun-Jul }\end{array}$ & $\begin{array}{c}(4) \\
\text { Jul-Aug }\end{array}$ & $\begin{array}{c}(5) \\
\text { Aug-Sep }\end{array}$ & $\begin{array}{c}(6) \\
\text { Sep-Oct }\end{array}$ & $\begin{array}{c}(7) \\
\text { Oct-Nov }\end{array}$ & $\begin{array}{c}(8) \\
\text { Nov-Dec }\end{array}$ \\
\hline Vulnerability index 2012 & & & & & & & & & \\
& $0.098^{*}$ & $0.084^{* *}$ & 0.055 & $0.12^{* * *}$ & -0.021 & $-0.082^{*}$ & 0.027 & 0.058 \\
& $(0.047)$ & $(0.032)$ & $(0.046)$ & $(0.030)$ & $(0.046)$ & $(0.040)$ & $(0.045)$ & $(0.038)$ \\
Observations & & & & & & 18 & 18 & 18 & 18 \\
R-squared & 18 & 18 & 18 & 18 & 18 & 0.12 & 0.02 \\
\hline
\end{tabular}

Note: The depreciation pressure index is based on currency depreciation and losses in foreign exchange reserves, with larger values indicating stronger depreciation pressure. Standard errors in parentheses, $* * * \mathrm{p}<0.01, * * \mathrm{p}<0.05, * \mathrm{p}<0.1$ 
Table 6: Examination of the April-August 2013 event: the increase in bond yields

(a) Cumulative stress

\begin{tabular}{|c|c|c|c|c|c|c|c|c|}
\hline $\begin{array}{l}\text { Dependent variable: } \\
\text { Increase in bond yields (ppt) }\end{array}$ & $\begin{array}{c}1) \\
\text { Apr-May } \\
\end{array}$ & $\begin{array}{c}(2) \\
\text { Apr-Jun } \\
\end{array}$ & $\begin{array}{c}(3) \\
\text { Apr-Jul }\end{array}$ & $\begin{array}{c}\text { (4) } \\
\text { Apr-Aug } \\
\end{array}$ & $\begin{array}{c}\text { (5) } \\
\text { Apr-Sep } \\
\end{array}$ & $\begin{array}{c}6) \\
\text { Apr-Oct } \\
\end{array}$ & $\begin{array}{c}7) \\
\text { Apr-Nov } \\
\end{array}$ & $\begin{array}{c}(8) \\
\text { Apr-Dec }\end{array}$ \\
\hline Vulnerability index 2012 & $\begin{array}{l}-0.013 \\
(0.011)\end{array}$ & $\begin{array}{l}0.022 \\
(0.023)\end{array}$ & $\begin{array}{l}0.047^{*} \\
(0.025)\end{array}$ & $\begin{array}{l}0.072^{* *} \\
(0.024)\end{array}$ & $\begin{array}{l}0.077^{* *} \\
(0.028)\end{array}$ & $\begin{array}{l}0.062^{* *} \\
(0.021)\end{array}$ & $\begin{array}{c}0.076^{* * *} \\
(0.023)\end{array}$ & $\begin{array}{l}0.094^{* * \star} \\
(0.027)\end{array}$ \\
\hline Observations & 14 & 14 & 14 & 14 & 13 & 13 & 14 & 14 \\
\hline R-squared & 0.11 & 0.07 & 0.22 & 0.44 & 0.40 & 0.44 & 0.47 & 0.50 \\
\hline
\end{tabular}

(b) Incremental stress

\begin{tabular}{lcccccccc}
\hline $\begin{array}{l}\text { Dependent variable: } \\
\text { Increase in bond yields (ppt) }\end{array}$ & $\begin{array}{c}(1) \\
\text { Apr-May }\end{array}$ & $\begin{array}{c}(2) \\
\text { May-Jun }\end{array}$ & $\begin{array}{c}(3) \\
\text { Jun-Jul }\end{array}$ & $\begin{array}{c}(4) \\
\text { Jul-Aug }\end{array}$ & $\begin{array}{c}(5) \\
\text { Aug-Sep }\end{array}$ & $\begin{array}{c}(6) \\
\text { Sep-Oct }\end{array}$ & $\begin{array}{c}(7) \\
\text { Oct-Nov }\end{array}$ & $\begin{array}{c}(8) \\
\text { Nov-Dec }\end{array}$ \\
\hline Vulnerability index 2012 & -0.013 & $0.036^{*}$ & $0.025^{*}$ & $0.026^{* * *}$ & 0.0059 & -0.015 & 0.015 \\
& $(0.011)$ & $(0.017)$ & $(0.013)$ & $(0.0073)$ & $(0.0070)$ & $(0.0093)$ & $(0.011)$ & $\left(0.018^{* *}\right.$ \\
& & & & & & 14 & 14 & 14 \\
Observations & 14 & 15 & 15 & 15 & 14 & 15 \\
R-squared & 0.11 & 0.25 & 0.22 & 0.50 & 0.06 & 0.18 & 0.13 & 0.32 \\
\hline
\end{tabular}

Note: Standard errors in parentheses, ${ }^{* * *} \mathrm{p}<0.01,{ }^{* *} \mathrm{p}<0.05,{ }^{*} \mathrm{p}<0.1$ 
Table 7: Differentiation across EMEs during past events: the depreciation pressure index

(a) Dependent variable: depreciation pressure index

\begin{tabular}{|c|c|c|c|c|c|c|c|}
\hline $\begin{array}{l}\text { Dependent variable: } \\
\text { Depreciation pressure index }\end{array}$ & $\begin{array}{c}(1) \\
\text { Aug } 1994-\text { Mar } 1995 \\
\end{array}$ & $\begin{array}{c}(2) \\
\text { Jun } 1997-\text { Jan } 1998 \\
\end{array}$ & $\begin{array}{c}(3) \\
\text { Jul-Nov } 1998 \\
\end{array}$ & $\begin{array}{c}(4) \\
\text { Mar-Oct } 2002 \\
\end{array}$ & $\begin{array}{c}(5) \\
\text { Aug } 2008-\text { Feb } 2009 \\
\end{array}$ & $\begin{array}{c}(6) \\
\text { Jun-Dec } 2011 \\
\end{array}$ & $\begin{array}{c}(7) \\
\text { Apr-Aug } 2013 \\
\end{array}$ \\
\hline Vulnerability index $(y-1)$ & $\begin{array}{r}-0.0079 \\
(0.015)\end{array}$ & $\begin{array}{c}0.042 \\
(0.043)\end{array}$ & $\begin{array}{l}0.078 \\
(0.051)\end{array}$ & $\begin{array}{c}0.055 \\
(0.043)\end{array}$ & $\begin{array}{l}0.071^{* *} \\
(0.033)\end{array}$ & $\begin{array}{l}0.097^{* * *} \\
(0.026)\end{array}$ & $\begin{array}{l}0.14^{* * *} \\
(0.027)\end{array}$ \\
\hline Observations & 18 & 15 & 19 & 18 & 19 & 20 & 20 \\
\hline R-squared & 0.02 & 0.07 & 0.12 & 0.09 & 0.21 & 0.43 & 0.61 \\
\hline
\end{tabular}

(b) Dependent variable: stock market change (\%)

\begin{tabular}{|c|c|c|c|c|c|c|c|}
\hline $\begin{array}{l}\text { Dependent variable: } \\
\text { Stock market change (\%) }\end{array}$ & $\begin{array}{c}(1) \\
\text { Aug } 1994-\text { Mar } 1995\end{array}$ & $\begin{array}{c}(2) \\
\text { Jun } 1997 \text { - Jan } 1998\end{array}$ & $\begin{array}{c}(3) \\
\text { Jul-Nov } 1998\end{array}$ & $\begin{array}{c}(4) \\
\text { Mar-Oct } 2002\end{array}$ & $\begin{array}{c}(5) \\
\text { Aug } 2008 \text { - Feb } 2009 \\
\end{array}$ & $\begin{array}{c}\text { (6) } \\
\text { Jun-Dec } 2011\end{array}$ & $\begin{array}{c}(7) \\
\text { Apr-Aug } 2013 \\
\end{array}$ \\
\hline Vulnerability index $(y-1)$ & $\begin{array}{l}-2.13^{*} \\
(1.07)\end{array}$ & $\begin{array}{l}-0.27 \\
(0.52)\end{array}$ & $\begin{array}{l}-0.67 \\
(1.11)\end{array}$ & $\begin{array}{l}-0.12 \\
(0.48)\end{array}$ & $\begin{array}{l}-0.25 \\
(0.36)\end{array}$ & $\begin{array}{r}-0.041 \\
(0.30)\end{array}$ & $\begin{array}{r}-0.074 \\
(0.27)\end{array}$ \\
\hline Observations & 12 & 10 & 15 & 16 & 16 & 17 & 17 \\
\hline R-squared & 0.28 & 0.03 & 0.03 & 0.00 & 0.03 & 0.00 & 0.01 \\
\hline
\end{tabular}

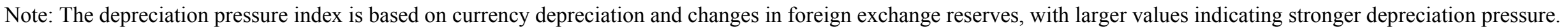

Standard errors in parentheses, $* * * \mathrm{p}<0.01, * * \mathrm{p}<0.05, * \mathrm{p}<0.1$ 
Figure 1: Financial performance April-August 2013

(1)

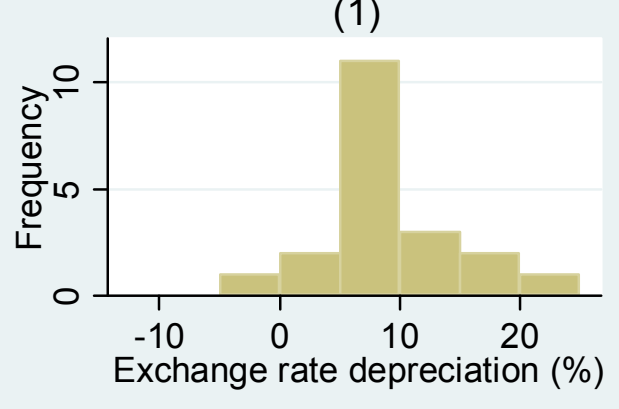

(4)

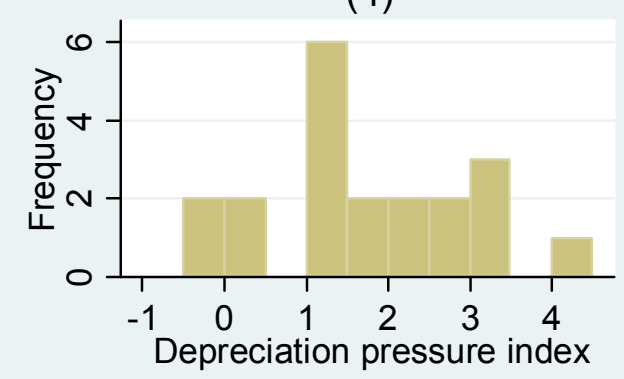

(7)

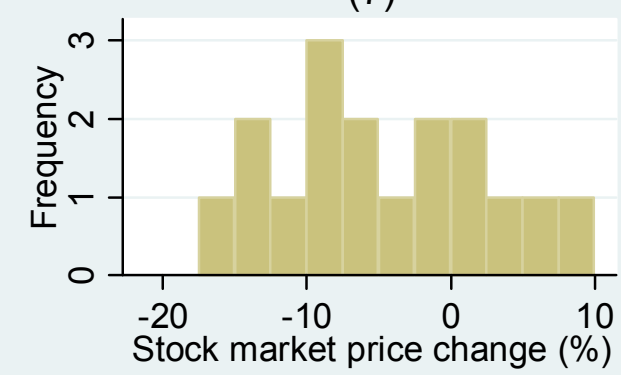

(2)

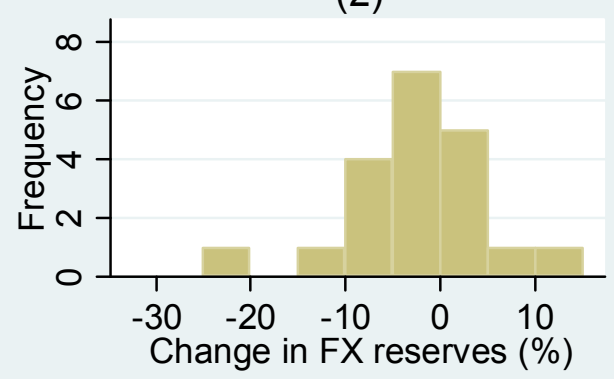

(5)

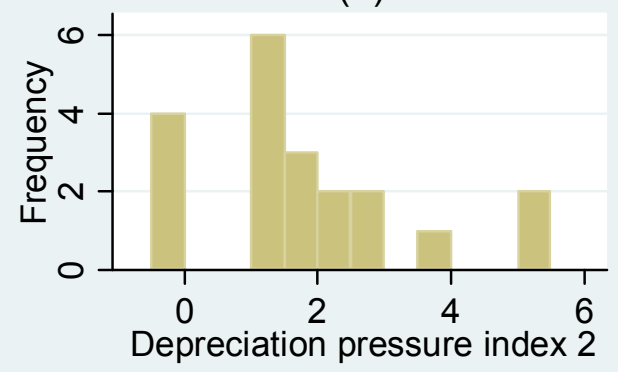

(8)

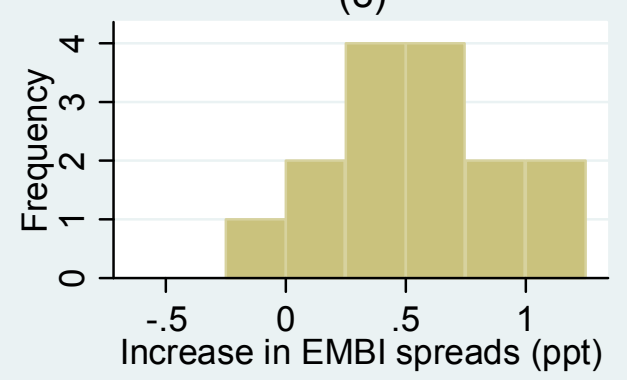

(3)

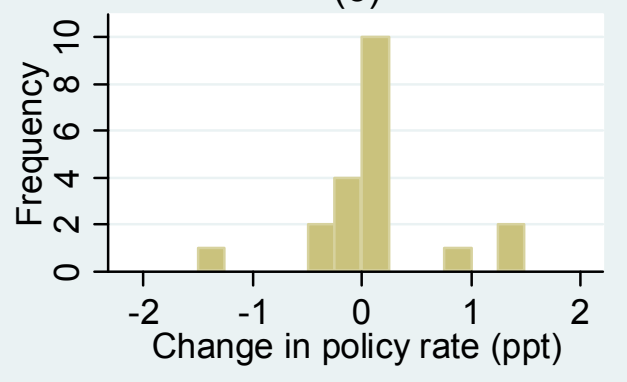

(6)

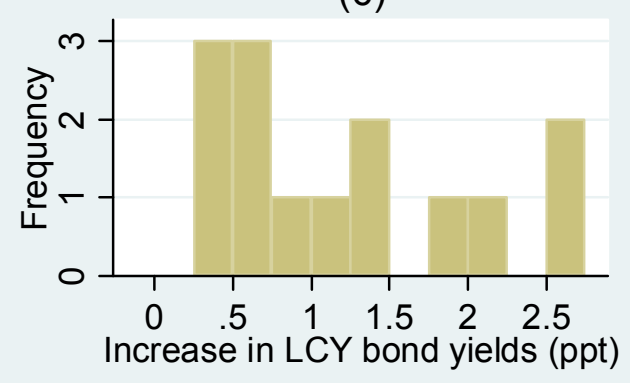

(9)

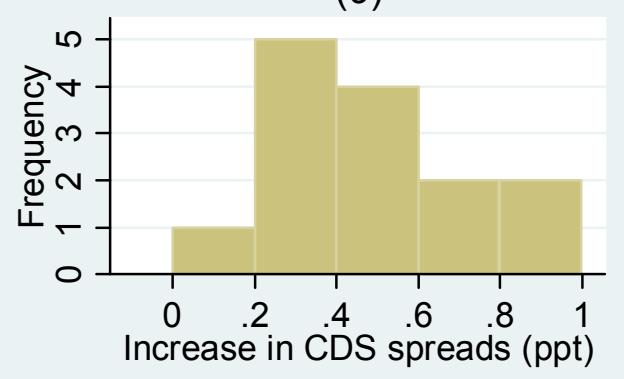

Note: Exchange rates are expressed as units of local currency to the dollar, so that positive changes in exchange rates indicate depreciation. The depreciation pressure index is based on currency depreciation and losses in foreign exchange reserves, with larger values indicating stronger depreciation pressure. As an alternative, the depreciation pressure index 2 is based on currency depreciation, losses in foreign exchange reserves, and policy rate increases, with larger values indicating stronger depreciation pressure. 
Figure 2: Exchange rate depreciation and macroeconomic fundamentals during April-August 2013

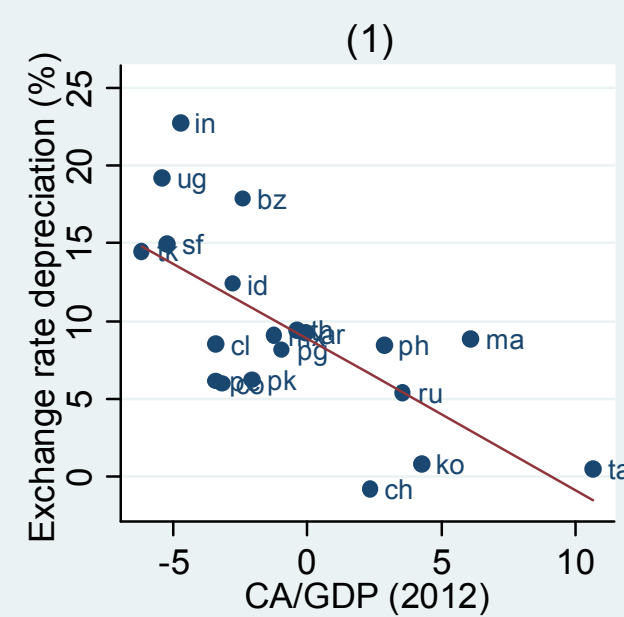

R-squared $=0.47$

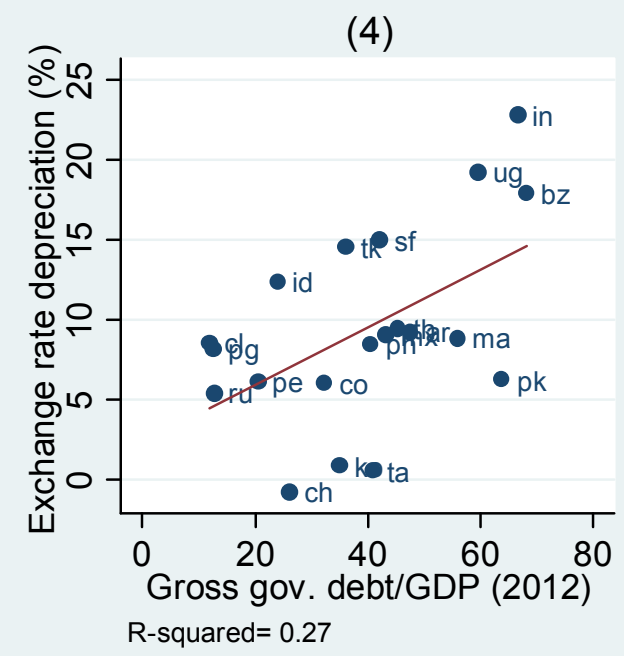

(2)

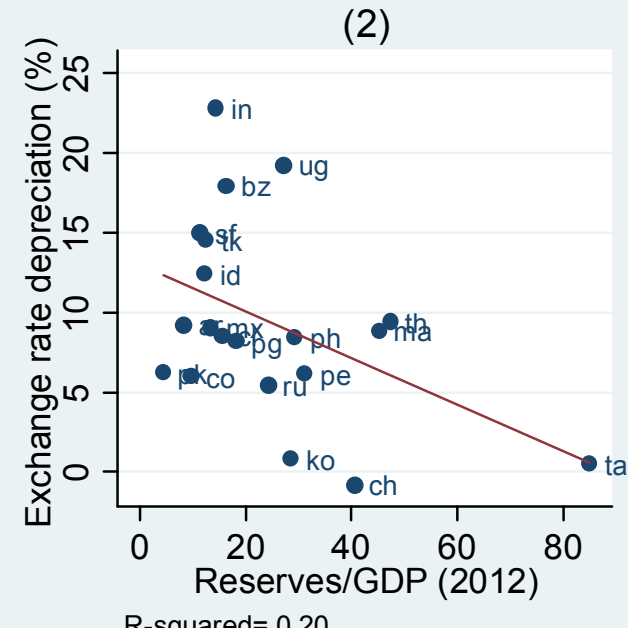

R-squared $=0.20$

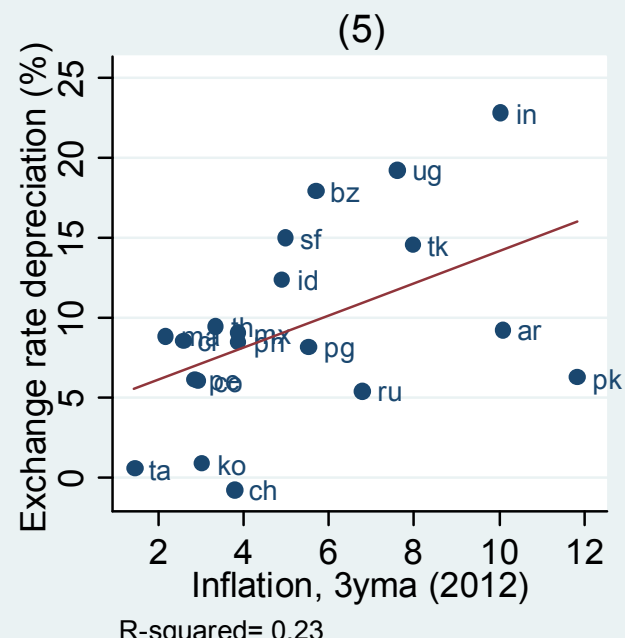

(3)

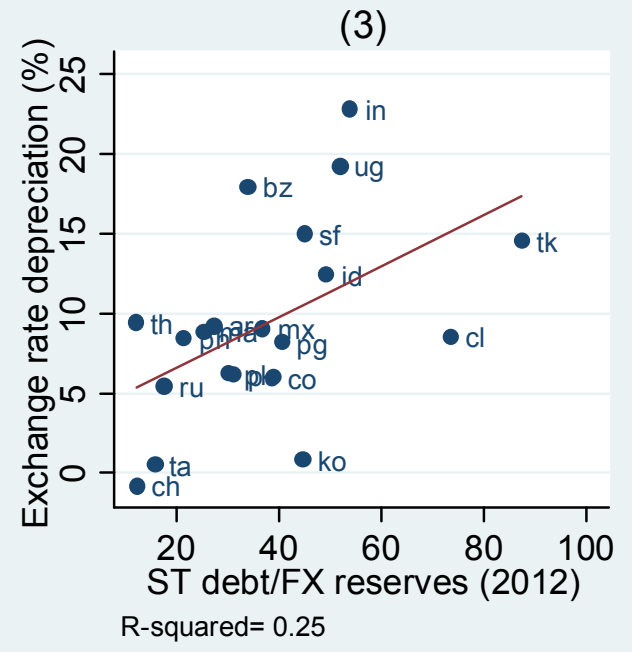

(6)

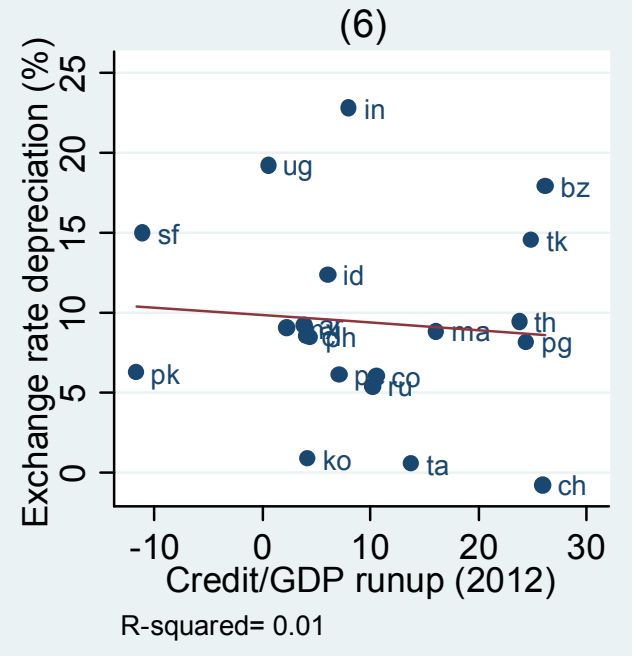


Figure 3: Increase in local currency government bond yields and macroeconomic fundamentals during April-August 2013

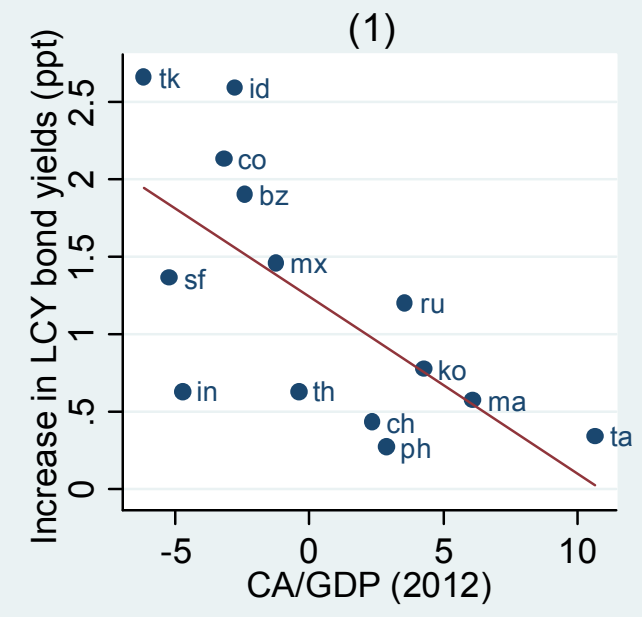

$\mathrm{R}$-squared $=0.45$

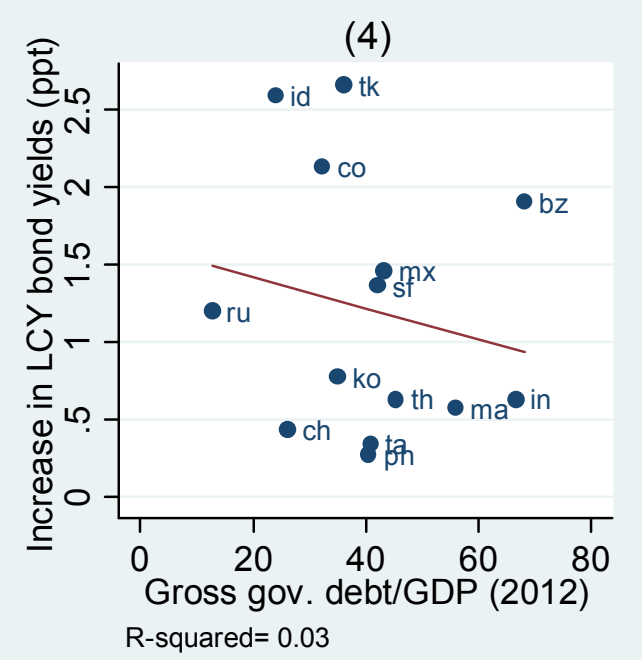

(2)
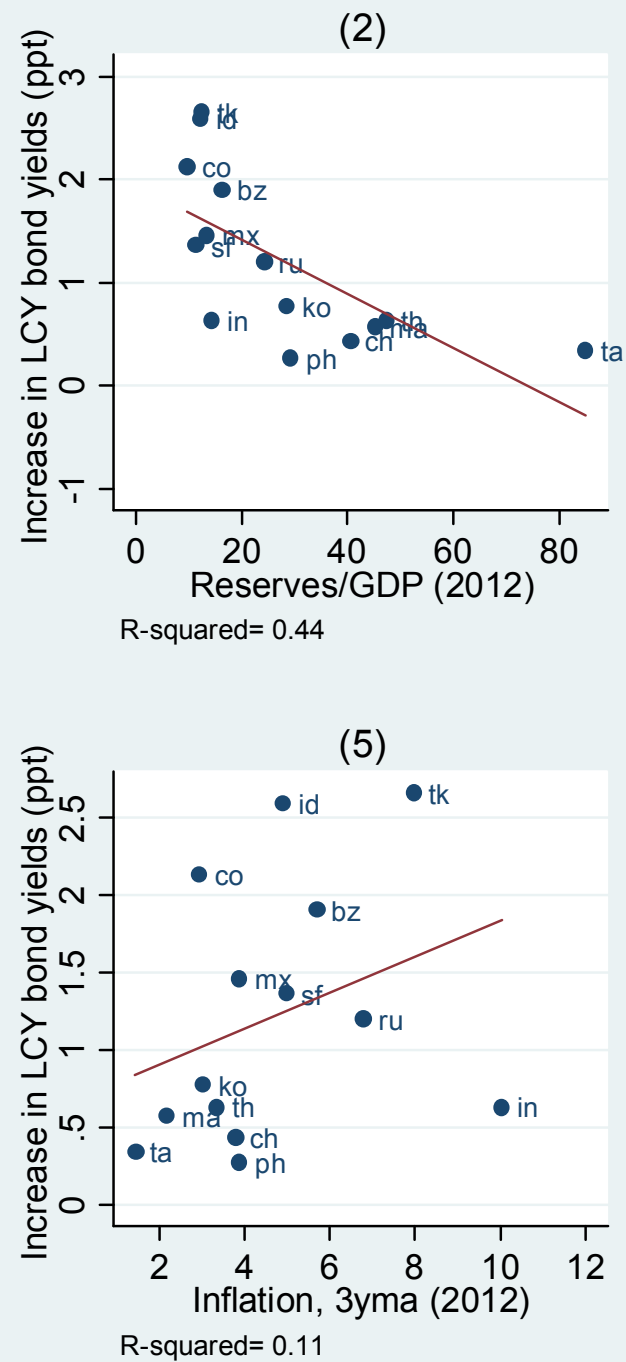

(3)

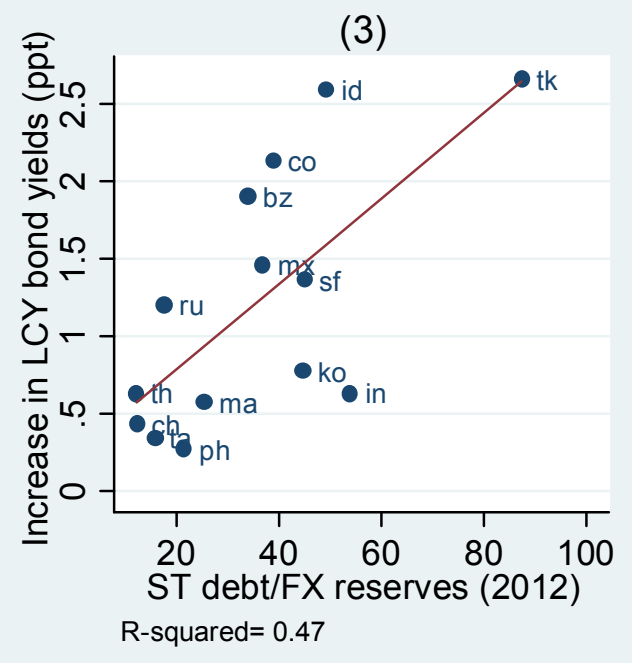

(6)

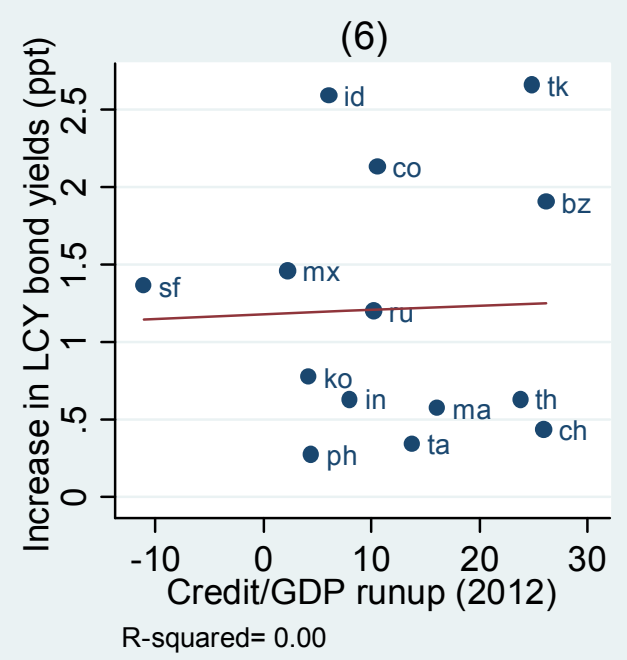


Figure 4: Identification of past events of financial stress

(a) VIX

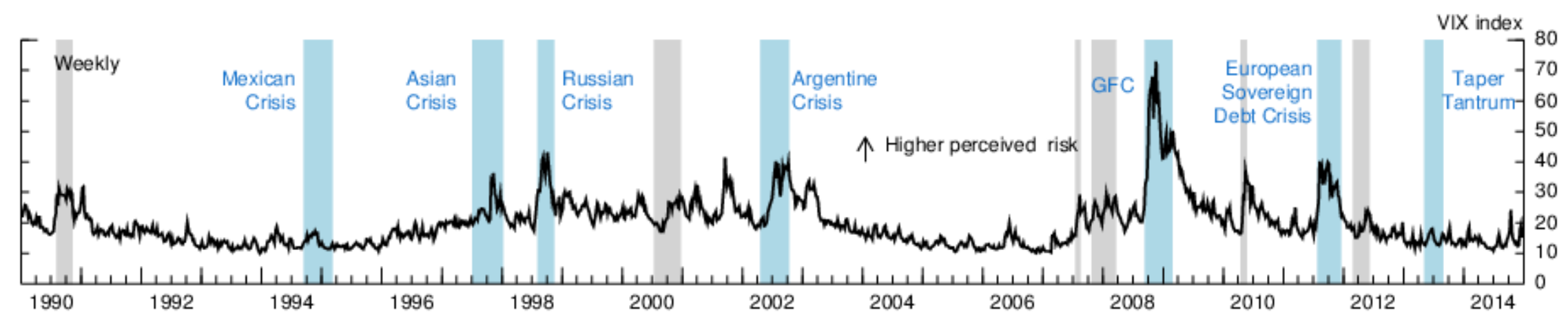

(b) OITP Dollar Index

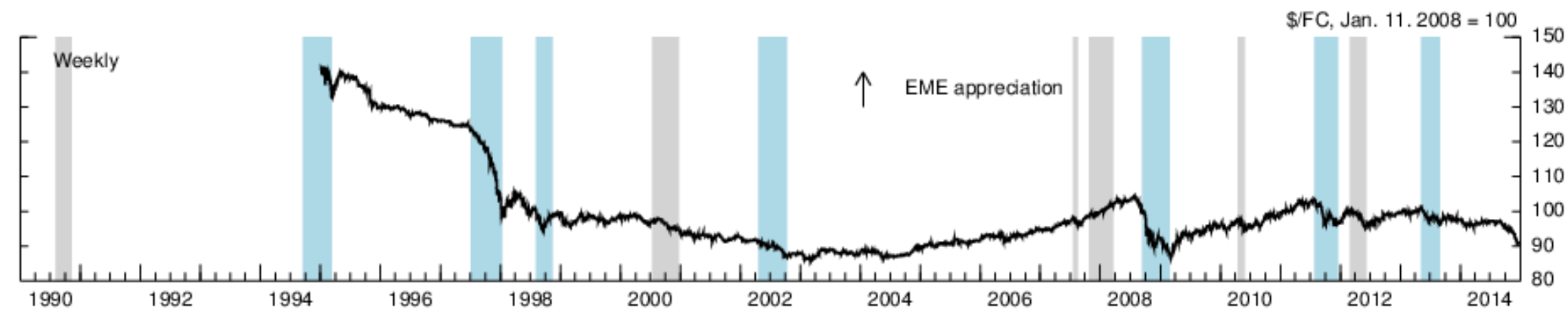

(c) MSCI Emerging Markets Local Currency Stock Index

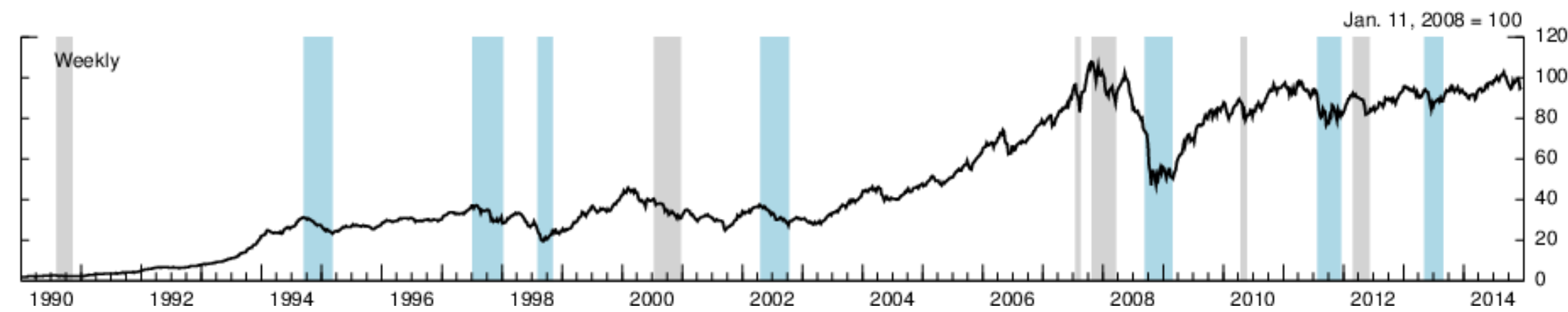

Note: The start and end dates for each of the 13 events in chronological order are as follows: (1) August 3 to November 9, 1990; (2) September 16, 1994 to March 10, 1995; (3) July 4 to August 29, 1997 and October 31, 1997 to January 9, 1998, merged in one single event; (4) August 7 to November 13, 1998; (5) July 14 to December 22, 2000; (6) April 19 to October 11, 2002; (7) July 20 to August 17, 2007; (8) October 26, 2007 to March 21, 2008; (9) September 12, 2008 to February 27, 2009; (10) April 16 to May 28, 2010;

(11) July 29 to December 16, 2011; (12) March 2 to June 8, 2012; and (13) May 10 to August 30, 2013. 
Figure 5: Depreciation pressure and economic fundamentals during past events of financial stress

(1) Aug 1994 - Mar 1995

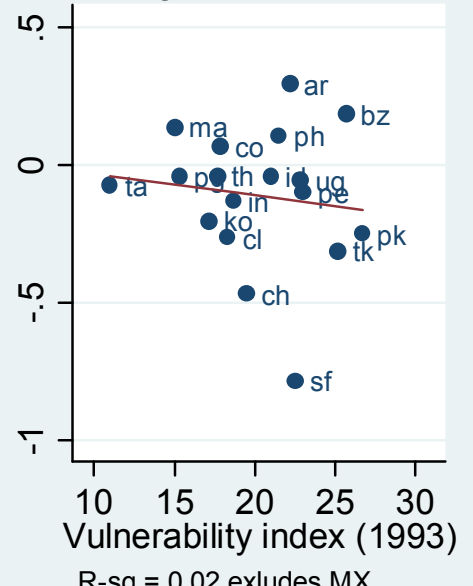

$\mathrm{R}$-sq $=0.02$ exludes $\mathrm{MX}$

(5) Aug 2008 - Feb 2009

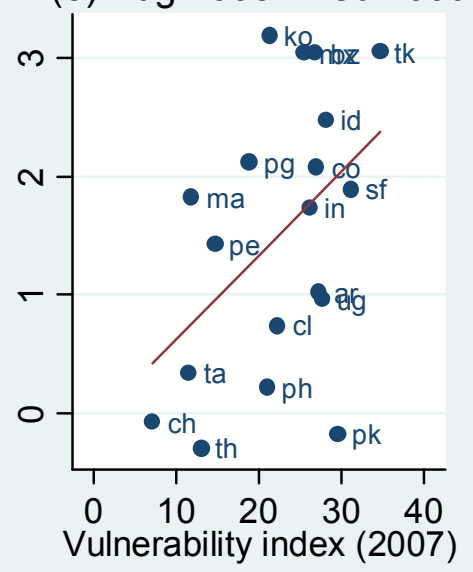

$\mathrm{R}$-sq $=0.21$ excludes $\mathrm{RU}$
(2) Jun 1997 - Jan 1998

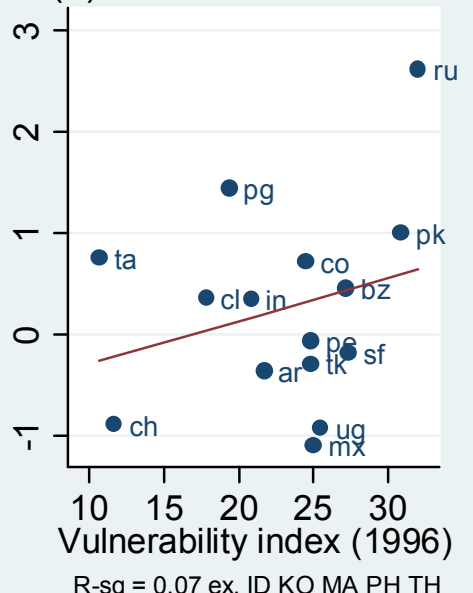

(6) Jun - Dec 2011

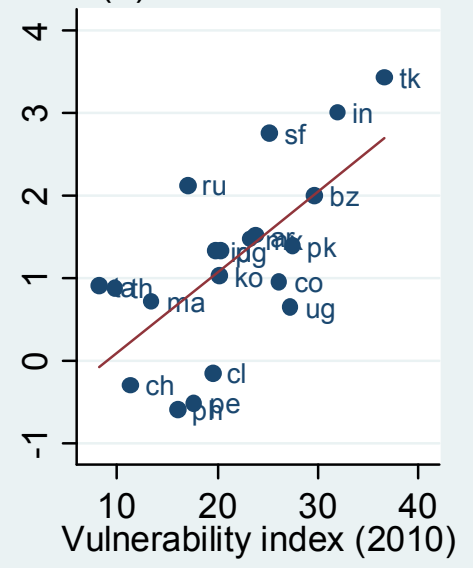

$\mathrm{R}$-sq $=0.43$
(3) Jul - Nov 1998

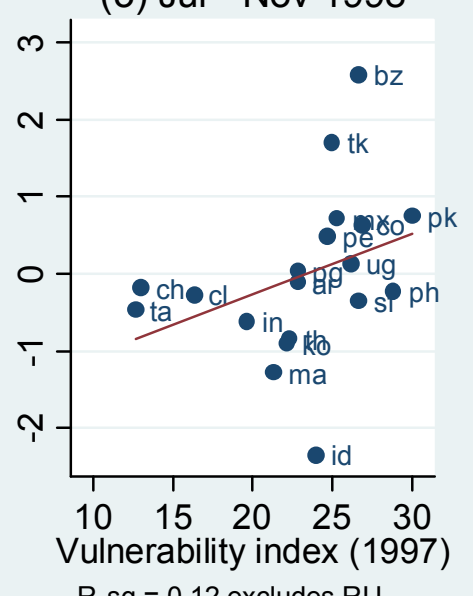

$\mathrm{R}$-sq $=0.12$ excludes $\mathrm{RU}$

(7) Apr - Aug 2013

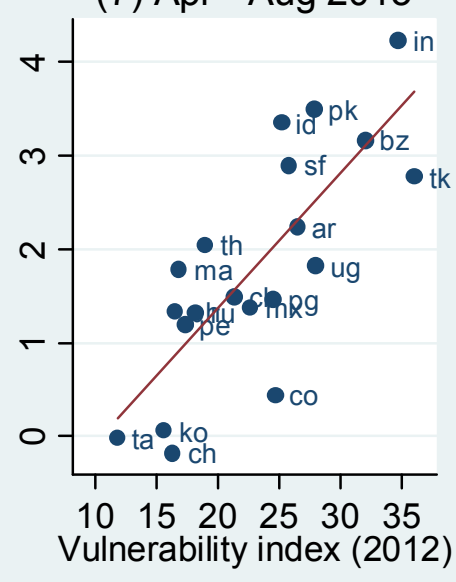

$\mathrm{R}$-sq $=0.61$
(4) Mar - Oct 2002

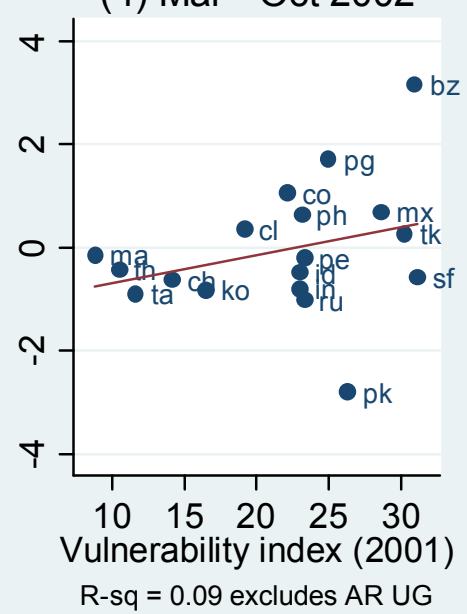

Note: For each event, the vertical axis shows the depreciation pressure index (based on currency depreciation and losses in foreign exchange reserves), with larger values indicating stronger depreciation pressure. 
Figure 6: Stock market declines and economic fundamentals during past events of financial stress

(1) Aug 1994 - Mar 1995

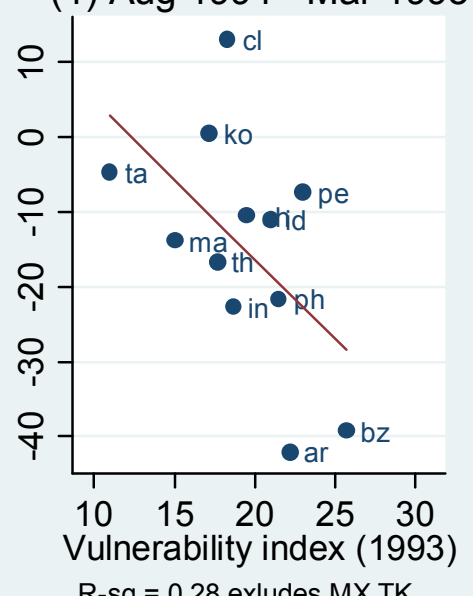

$\mathrm{R}$-sq $=0.28$ exludes $\mathrm{MX} \mathrm{TK}$

(5) Aug 2008 - Feb 2009

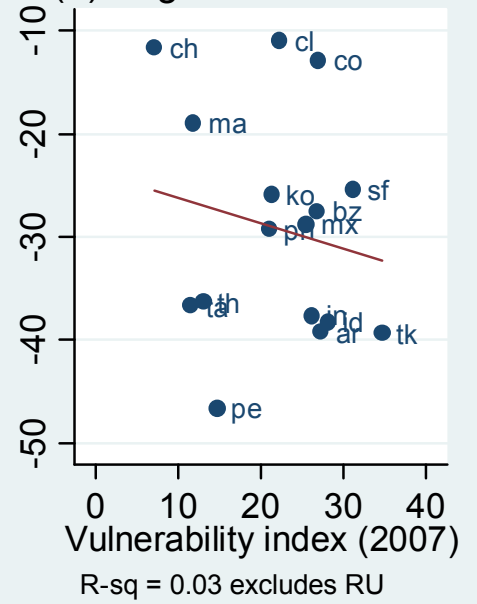

(2) Jun 1997 - Jan 1998

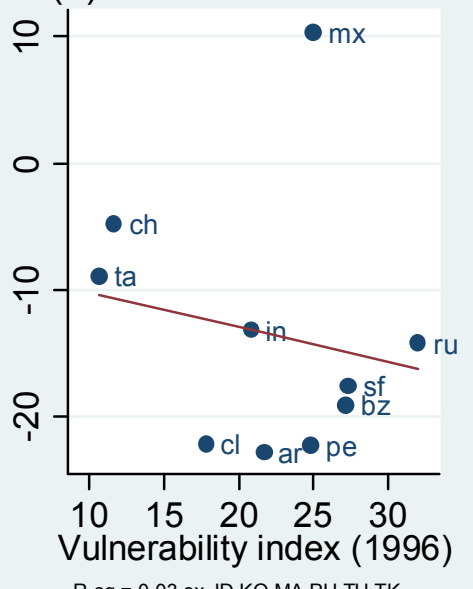

(6) Jun - Dec 2011

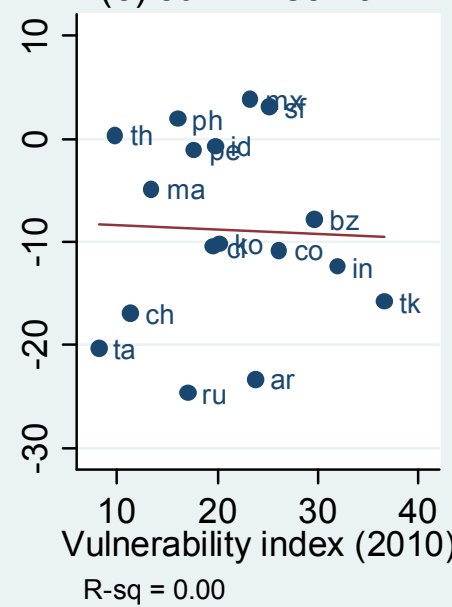

(3) Jul - Nov 1998

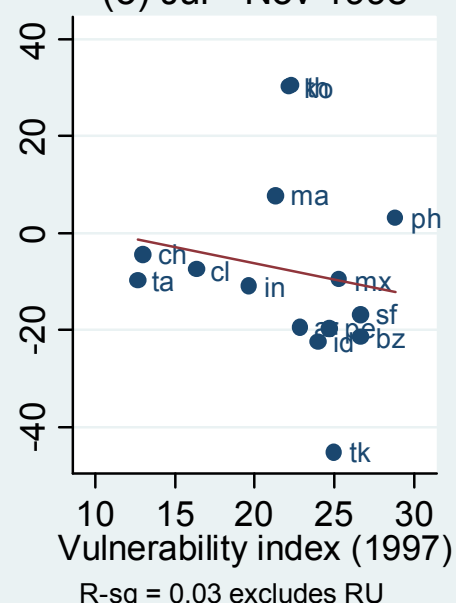

(7) Apr - Aug 2013

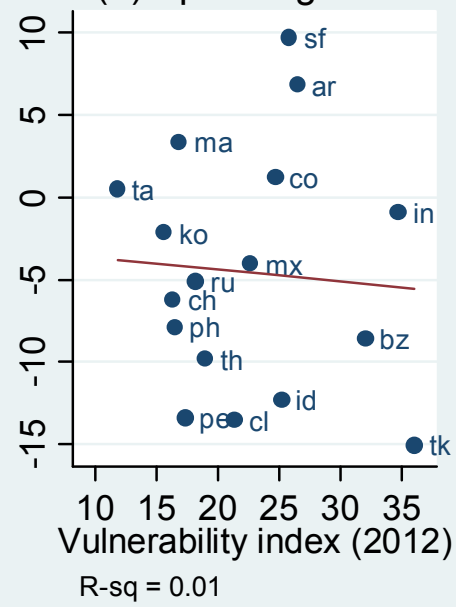

(4) Mar - Oct 2002

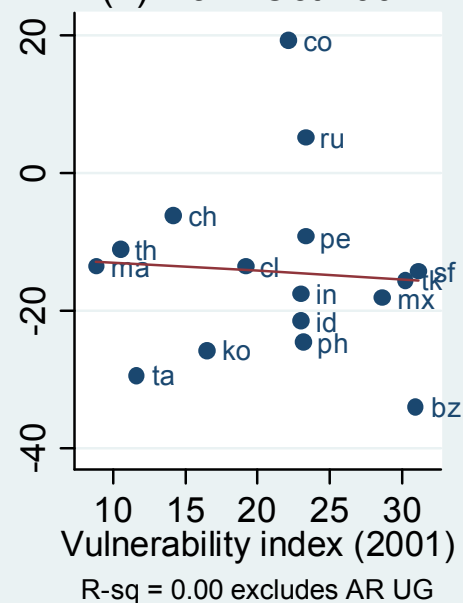

Note: For each event, the vertical axis shows the percentage change in the local stock market index. 